The Flowing Wells of Central Australia (Continued)

Author(s): J. W. Gregory

Source: The Geographical Journal, Vol. 38, No. 2 (Aug., 1911), pp. 157-181

Published by: geographicalj

Stable URL: http://www.jstor.org/stable/1778704

Accessed: 12-06-2016 06:11 UTC

\title{
REFERENCES
}

Linked references are available on JSTOR for this article: http://www.jstor.org/stable/1778704?seq=1\&cid=pdf-reference\#references_tab_contents You may need to log in to JSTOR to access the linked references.

Your use of the JSTOR archive indicates your acceptance of the Terms \& Conditions of Use, available at

http://about.jstor.org/terms

JSTOR is a not-for-profit service that helps scholars, researchers, and students discover, use, and build upon a wide range of content in a trusted digital archive. We use information technology and tools to increase productivity and facilitate new forms of scholarship. For more information about JSTOR, please contact support@jstor.org.

The Royal Geographical Society (with the Institute of British Geographers), Wiley are collaborating with JSTOR to digitize, preserve and extend access to The Geographical Journal 
other subjects, these have been omitted from the geographical ones. Yet such pictures are as important in geographical articles as in others.

To conclude, we have in the new edition of the 'Encyclopædia Britannica' the best gazetteer and the most adequate collection of articles on geographical subjects in our language. Though we have dwelt on its deficiencies, its nineteenth century scrappiness in places, and its neglect of important aspects of the subjects, its inadequate bibliographies, and still more inadequate illustrations, this must not be taken to mean that we do not recognize that it is a great advance on any other work in our language, and that it is a monument of erudition and careful editing, which on most matters can be trusted to give the best information in a clear and satisfactory manner.

A. J. H.

\section{THE FLOWING WELLS OF CENTRAL AUSTRALIA.*}

By Prof. J. W. GREGORY, D.Sc., F.R.S.

\section{The Diffiodltims of the Water Pressure Theory.}

(a) The Limitations of Water Pressure.

If the wells are not now maintained by annual inflow, but are discharging accumulations of residual water, of water due to ancient infiltration, and of water from a plutonic source, what is the cause of their overflow ? There are probably three factors at work, of which water-pressure is doubtless one. Water in the lower end of an inclined tube or sheet of water is necessarily under pressure from that at a higher end, and if the water be flowing it is under hydraulic pressure, and if the water be stationary it is under hydrostatic pressure. $\dagger$ Water in any inclined bed is necessarily under a certain amount of hydraulic or hydrostatic pressure. But the friction on water moving through fine tubes or fine-grained rocks places a definite limit on the distance to which this pressure can act in uplifting water. The friction of the passage of water through the fine pores of rocks at a rate sufficient to maintain a large flow from the wells soon absorbs the pressure due to head.

Mr. Knibbs has replied that I have exaggerated the retarding effect of friction owing to having overlooked the slow rate of movement that would suffice to maintain the discharge from the wells. Mr. Knibbs's paper was issued in reply to the report in the Australian Mining Standard of a few remarks made during the course of a lecture at Bendigo on the formation of ore deposits. Mr. Knibbs's paper was published by the Royal Society of New South Wales in 1903, so that I might have been expected to have read it before writing on the question in 1905. The volume was, however, not available to geologists in this country until long after that date. $\neq$

* Continued from p. 59. Map, p. 232.

$\dagger$ When water is moving so slowly that it is practically stationary the conditions are generally described as hydrostatic.

I I had examined the last volumes of that journal available, and I still happen to have the application slip for that volume returned " not received" when I applied for it in 1905. The librarians at the British Museum (Nat. Hist.) and at the Geological Society have kindly told me that the volume for 1903 was not received by them until 
Mr. Knibbs explains the slow movement of the water that would suffice to maintain the wells by a formula,* which is a mathematical expression of the fact that the diameter of a big circle is much larger than that of a very small one, Mr. Knibbs's formula $\dagger$ is so simple that it would prove too much, for, as he says, the discharge from a bore drawing water from a wide area would be maintained by a movement of the water so slow that it might be regarded as almost infinitely small and therefore frictionless. If so, and if Mr. Knibbs's formula were an adequate expression of the facts, the loss of head should also be infinitely small ; but the loss of head is admittedly considerable, as is obvious from the isopotential map of any large artesian basin or to the ordinary "plane of head" of subterranean water. $\ddagger$

In spite of Mr. Knibbs's formula, water percolating through the minute cavities in porous rocks is unquestionably greatly retarded by friction $\S$ and other factors. Mr. Knibbs's formula, like others, is of no practical value when applied to great distances and to water which sinks so deep below the earth's surface that its temperature is greatly raised. Many formulæ have been given, showing the loss of head due to the frictional resistance encountered by percolating water. The standard formula at present is Hazen's, and the loss of head in loose deposits of various grades and at various rates of flow according to that formula are shown in the table on the following page.\|

That table may be useful as showing the different loss of head in various loose sediments, and it must be remembered that the effective porosity of such materials is materially reduced when they are consolidated into firm rocks.

Mr. Knibbs's formula might, however, have been very useful to Mr. Pittman if it had prevented his oversight of the importance of velocity on the retardation by friction of the flow of water. To illustrate the power of friction on flowing water I quoted from Box's "Hydraulics," a case in which the mere roughness of the inside of a one-inch pipe held back the water to an extent equal to a loss of

August, 1908. If the Royal Society of Sydney only sends its journal to the standard British libraries five years after publication, it is not surprising if its papers do not receive the attention they deserve.

$* \mathrm{~V}=\frac{v r}{\mathrm{R}}$, in which $r=$ radius of bore, $\mathrm{R}$ distance of point considered from the centre of the bore, $v=$ velocity at the bore, $\mathrm{V}=$ velocity at the distance $\mathrm{R}$. (Journ. R. Soc. N. S. Wales, vol. 37, p. xxix. 1903).

$\dagger$ Mr. Knibbs's calculations based on this formula have been disputed by G. W. Grabham, who says that the results are twelve times too large ("Notes on some Recent Contributions to the Study of Desert Water-Supplies," Cairo Sci. Journ., vol. 4, p. 170. July, 1910).

† I am glad to find that Mr. Knibbs agrees with me upon the practical question at issue. He remarks that it " may be fairly inferred from what he [i.e. myself] says, viz. that the supply may be exhausted" (p. xlvii.); and that "we may be recklessly playing with an economic capital which it has taken centuries to accumulate." Every bore, he concludes, not utilized should be shut down (p. xxxii.).

$\S$ Professor David, though an advocate of the water-pressure theory for the Australian wells, remarks on the limitation imposed by " the vast frictional resistance which would be offered by the beds of fine sand which would have to be traversed by the artesian water," (T. W. E. David, "Notes on Artesian Water in New South Wales," Journ. R. Soc. N. S. Wales, vol. 27, p. 427. 1893).

|| Hazen's original paper being somewhat inaccessible, reference may be made to its explanation by Slichter, "The Motions of Underground Waters," Water Supply Papers of the United States Geol. Surv. No. 67, pp. 22-23. 1902. 
head of 700 feet in 100 miles. Mr. Pittman correctly quoted the data, including the statement that the one-inch pipe was discharging a gallon a minute; but he denies the possibility of this case, because the artesian wells in Paris have a loss of only 136 feet, instead of 700 feet, in 100 miles. He entirely overlooks the factor of velocity. The one-inch pipe in question and spaces of equal size in the Paris sands would only lose head at the same rate if the water were flowing through the latter at the rate of a gallon a minute through each circular inch.

Table of Loss of Head in Silt, Sand, and Fine Gravel.

\begin{tabular}{|c|c|c|c|c|c|c|c|}
\hline \multirow{2}{*}{ Velocity. } & \multirow{2}{*}{\multicolumn{2}{|c|}{ Effective size of grains. }} & \multirow{2}{*}{ Temp. } & \multicolumn{4}{|c|}{ Distance. } \\
\hline & & & & 1 mile. & 10 miles. & 50 miles. & 100 miles. \\
\hline 1 yard & $\begin{array}{l}\text { inch. } \\
0.001\end{array}$ & $\begin{array}{c}\mathrm{mm} . \\
0.025\end{array}$ & $\begin{array}{c}\text { - Fahr. } \\
50\end{array}$ & $\begin{array}{l}\text { feet. } \\
7 \cdot 0\end{array}$ & $\begin{array}{l}\text { feet. } \\
70.5\end{array}$ & $\begin{array}{r}\text { feet. } \\
353 \cdot 0\end{array}$ & $\begin{array}{r}\text { feet. } \\
706 \cdot 0\end{array}$ \\
\hline \multirow[t]{2}{*}{ per day. } & (coarse & lay or & 100 & 3.85 & 38.5 & 192.5 & $385 \cdot 0$ \\
\hline & silt & & 150 & $2 \cdot 65$ & $26 \cdot 5$ & $132 \cdot 0$ & $265 \cdot 0$ \\
\hline \multirow{3}{*}{$"$} & 0.005 & 0.125 & 50 & $0 \cdot 28$ & 2.8 & $14 \cdot 0$ & $28 \cdot 0$ \\
\hline & (fine & and) & 100 & $0 \cdot 15$ & 1.5 & 7.7 & $15 \cdot 4$ \\
\hline & & & 150 & $0 \cdot 11$ & 1.0 & $5 \cdot 0$ & $10 \cdot 6$ \\
\hline \multirow[t]{3}{*}{$"$} & 0.03 & 0.75 & 50 & 0.008 & 0.08 & $0 \cdot 4$ & $0 \cdot 8$ \\
\hline & (coarse & and) & 100 & $0 \cdot 004$ & 0.04 & $0 \cdot 2$ & $0 \cdot 4$ \\
\hline & & & 150 & 0.003 & 0.03 & $0 \cdot 15$ & $0 \cdot 3$ \\
\hline \multirow{3}{*}{$"$} & $0 \cdot 15$ & $3 \cdot 75$ & 50 & 0.0002 & 0.002 & 0.01 & 0.02 \\
\hline & (fine & ravel) & 100 & 0.0002 & 0.002 & 0.009 & $0 \cdot 017$ \\
\hline & & & 150 & 0.0001 & 0.001 & 0.006 & $0 \cdot 012$ \\
\hline \multirow{3}{*}{$\begin{array}{l}5 \text { yards } \\
\text { per day. }\end{array}$} & 0.001 & 0.025 & 50 & $35 \cdot 0$ & $352 \cdot 0$ & $1765 \cdot 0$ & $3530 \cdot 0$ \\
\hline & & & 100 & $19 \cdot 0$ & 192.5 & 962.5 & $1925 \cdot 0$ \\
\hline & & & 150 & $13 \cdot 0$ & $131 \cdot 6$ & $658 \cdot 0$ & $1316 \cdot 0$ \\
\hline \multirow[t]{3}{*}{$"$} & 0.005 & 0.125 & 50 & $1 \cdot 4$ & $14 \cdot 0$ & $70 \cdot 6$ & $141 \cdot 0$ \\
\hline & & & 100 & $0 \cdot 8$ & $7 \cdot 7$ & $38 \cdot 5$ & $77 \cdot 0$ \\
\hline & & & 150 & 0.5 & $5 \cdot 0$ & $26 \cdot 5$ & $53 \cdot 0$ \\
\hline \multirow[t]{3}{*}{ " } & 0.03 & 0.75 & 50 & 0.04 & $0 \cdot 39$ & $2 \cdot 0$ & $4 \cdot 0$ \\
\hline & & & 100 & 0.02 & 0.21 & $1 \cdot 1$ & $2 \cdot 2$ \\
\hline & & & 150 & 0.015 & 0.15 & 0.7 & 1.5 \\
\hline \multirow[t]{3}{*}{$"$} & 0.15 & $3 \cdot 75$ & 50 & $0 \cdot 001$ & 0.01 & 0.07 & $0 \cdot 155$ \\
\hline & & & 100 & 0.001 & 0.01 & 0.045 & 0.085 \\
\hline & & & 150 & 0.0005 & 0.005 & 0.03 & 0.06 \\
\hline \multirow{3}{*}{$\begin{array}{l}20 \text { yards } \\
\text { per day. }\end{array}$} & 0.001 & 0.025 & 50 & $141 \cdot 2$ & 1411.0 & 7059.0 & 14180 \\
\hline & & & 100 & 77.0 & $770 \cdot 0$ & $3850 \cdot 0$ & $7700 \cdot 0$ \\
\hline & & & 150 & $53 \cdot 0$ & 531.0 & 2654.0 & $5307 \cdot 0$ \\
\hline \multirow[t]{3}{*}{$"$} & 0.005 & 0.125 & 50 & $5 \cdot 6$ & $56 \cdot 5$ & 282.0 & 565.0 \\
\hline & & & 100 & $3 \cdot 1$ & 30.8 & 154.0 & $308 \cdot 0$ \\
\hline & & & 150 & $2 \cdot 1$ & 21.0 & 105.0 & 211.0 \\
\hline \multirow[t]{3}{*}{$"$} & 0.03 & 0.75 & 50 & 0.16 & 1.6 & $7 \cdot 8$ & 15.7 \\
\hline & & & 100 & 0.08 & 0.86 & 4.3 & 8.6 \\
\hline & & & 150 & 0.06 & 0.58 & 2.9 & 5.9 \\
\hline \multirow[t]{3}{*}{ ", } & 0.15 & 3.75 & 50 & 0.004 & 0.04 & 0.25 & 0.5 \\
\hline & & & 100 & 0.003 & 0.04 & 0.18 & 0.34 \\
\hline & & & 150 & 0.002 & 0.02 & 0.12 & 0.24 \\
\hline
\end{tabular}

Mr. Pittman also fails to appreciate the difference of flow in pipes or large channels and that in pipettes or porous rock. He replies to the view that friction would absorb the head of the water in a long passage through sandstone by the statement that the loss of head is as the square of the velocity, and misquotes me as supporting that statement. I cited two formulæ to explain the flow of water in pipes and pipettes,* and Mr. Pittman quotes the wrong one. He applies the rules for the flow of water in large pipes to its flow through porous rocks; the

* 'The Dead Heart of Australia,' p. 303. 
formula for pipettes should have been adopted and it shows that in them the loss of head varies as the velocity, and not as the square of the velocity.*

\section{(b) The Irregularities in Potential Level.}

The fundamental difficulties in explaining the flowing wells of Central Australia by water-pressure are the irregularities in the level to which the water rises and the irregular distribution of the flows. The hydrostatic theory is expressed by the well-known dictum that water will find its own level; and in U tubes or in water pipes under the uniform conditions of a city supply, water does find its own level; but the conditions which control the flow of water through a variable series of rocks are so complex that I know of no area where water does find its own level at a great distance from its intake. "The plane of the water head" is always a slope. Even under the conditions most favourable to the free circulation, the water does not rise to its own level in wells 100 miles from the intake. Thus in Dakota the potential level 20 miles east of the Black Hills is at 3000 feet; it falls 1200 feet in the first 170 miles to the east, or $6 \frac{1}{2}$ feet in the mile, and then 200 feet more in the next 130 miles, or $1 \frac{1}{2}$ feet in the mile. $†$

The water level in a well or the level to which the water in a flowing well would rise in a pipe placed over the mouth, is its potential ; lines and surfaces drawn through points where the potential is at the same height above sea level are the isopotential lines and surfaces.

If the conditions be absolutely hydrostatic, then the isopotentials form a level surface; if the conditions be hydraulic, then the isopotential lines occur on a slope, which need not be uniform in grade but would always be downward from the intake.

The water-pressure theory is inconsistent with the water rising, either above the level of its intake, or above the level of the lowest outcrop of the intake bed, unless, in the latter case, the frictional resistance to the passage of the water from its entrance to the low-lying outcrop is greater than that from its entrance to the water-level in the wells. The isopotential maps of the Australian flowing wells $\ddagger$ show that there are many cases in which the potential rises away from the assumed intake bed, while the distribution of areas of high and low potential are quite inconsistent with the theory that the water is absorbed by the Blythesdale Braystone or the Jurassic sandstones and flows through them under the central basin. The section issued with Mr. Pittman's "Clarke Lecture" from Brisbane, through Toowoomba and Longreach to the Gulf of Carpentaria, also shows that the potential surface varies irregularly and exceeds the level of the eastern margin of the supposed intake. Thus the potential surface is below 1100 feet between Dalby and Canobie ; it rises to 1300 feet near Morven, and falls to 1200 feet at Charleville, and to 900 feet at Longreach, thence continuing north-westward the potential rises to over 900 feet between the Darr river downs and Sesbania, and thence sinks towards the Gulf of Carpentaria. It may be argued that the two rises in potential along this line are due to water coming from secondary sources of supply, in beds outcropping to the north-east of the line of section. That

* Williams has given two curves of supply for Queensland wells, and remarks that the flow varies as the head, and not as the square root of the head, as would be expected on the ordinary theory (Min. Proc. Inst. Civ. Eng., vol. 159, pp. 319-321. 1905).

$\dagger$ Map in Darton's ' Preliminary Report on the Geology and Underground Water Resources of the Central Great Plains,' Dept. of the Interior, U.S. Geol. Survey, Professional Paper No. 32, pl. lix. 1905.

$\ddagger$ A map of the isopotential lines is given as Map No. II, ' Dead Heart of Australia.' 
explanation is, however, difficult on Mr.Pittman's view that the Jurassic sandstones are the intake, for these rocks do not extend so far to the north-west, and do not approach within $\mathbf{7 0}$ miles of Charleville; and if there be a secondary intake from beds at a high level north-east of Charleville, the flow from it should be southeastward towards the area of Jurassic sandstones near Toowoomba instead of the assumed flow in the reverse direction.

Professor David and Mr. J. Baillie Henderson have both pointed out that the rise of the water in some of the wells could not be explained by hydrostatic pressure. Thus Professor David * remarked in 1893 that the water at the Charleville well would rise to the level of 1197 feet, which, he says, is "about equal to the level of the intake," 140 miles away ; and Mr. Henderson pointed out in his annual report for 1893-4 that the water in this well would rise to 1198 feet above sea level or higher than the Cretaceous intake beds except at a few points. + To explain this anomaly, Professor David made a suggestion which he dismissed as "extremely doubtful." And, as a matter of fact, even if the



supposed intake beds rise at one place to 1200 feet, they have a free discharge to the surface near Roma, at 987 feet, i.e. level with the surface of the ground at Charleville. Why should water in a bed of sandstone at the height of 1200 feet force water by either hydrostatic or hydraulic pressure to the same height at a place over 100 miles away, while there is a free outlet near at hand at 1000 feet. Again, Professor David remarks that the water of the well at Cunnamulla would rise to the level of 1008 feet (or perhaps 1100 feet), although it is 220 miles from its assumed intake, the Blythesdale Braystone near Roma; and that bed outcrops at the level of only 1065 feet at Hodgson, west of Roma, and of 987 feet at Blythesdale, east of Roma, and for a width of 7 miles past Pickanjennie and Wallumbilla it is at the level of a little over 1000 feet. $\ddagger$ So the water that flows into the Blythesdale Braystone in the Roma district rises 200 miles away in the

* T. W. E. David, "Notes on Artesian Water in New S. Wales and Queensland," Part II., Jour. R. Soc. N. S. Wales, vol. 27, p. 426.1893.

$\dagger$ The potential level, according to Mr. Henderson's Tables, 1908, is 1161 feet, so it has fallen somewhat.

$\ddagger$ The levels of the two railway stations on the Blythesdale Braystone there are 1019 and 1032 feet.

No. II.-AUgust, 1911.] 
wells of Thargomindah, Bando and Cunnamulla, to the levels of 1048, 1071 and 1100 feet, or to a greater height than the outcrop of the intake bed near the entrance of the water! The water rises not only to its own level, but exceeds the level at which it might freely escape from the assumed intake.

Again in northern Queensland, the surface level of a flowing well at Kynuna is 655 feet above the sea, and the water would rise above it to the level of 722 feet; the level of the nearest outcrop of Blythesdale Braystone at Saxby Downs 120 miles away (see Fig. 7), is given by Henderson * for one place as 496 feet. Why should not the water escape at Saxby Downs, instead of at level 128 feet higher, at a locality 120 miles distant ? Moreover, the Braystone has a continuous outcrop descending northward from Saxby Downs till it is only 100 feet above the sea.

If it be replied that the wells of the Kynuna district are not fed by the northern area of Blythesdale Braystone, then it is admitted that the area of that rock,

SURFACE LEVEL AND POTENTIAL LEVEL OF WELLS FROM LONGREACH TO COREENA.

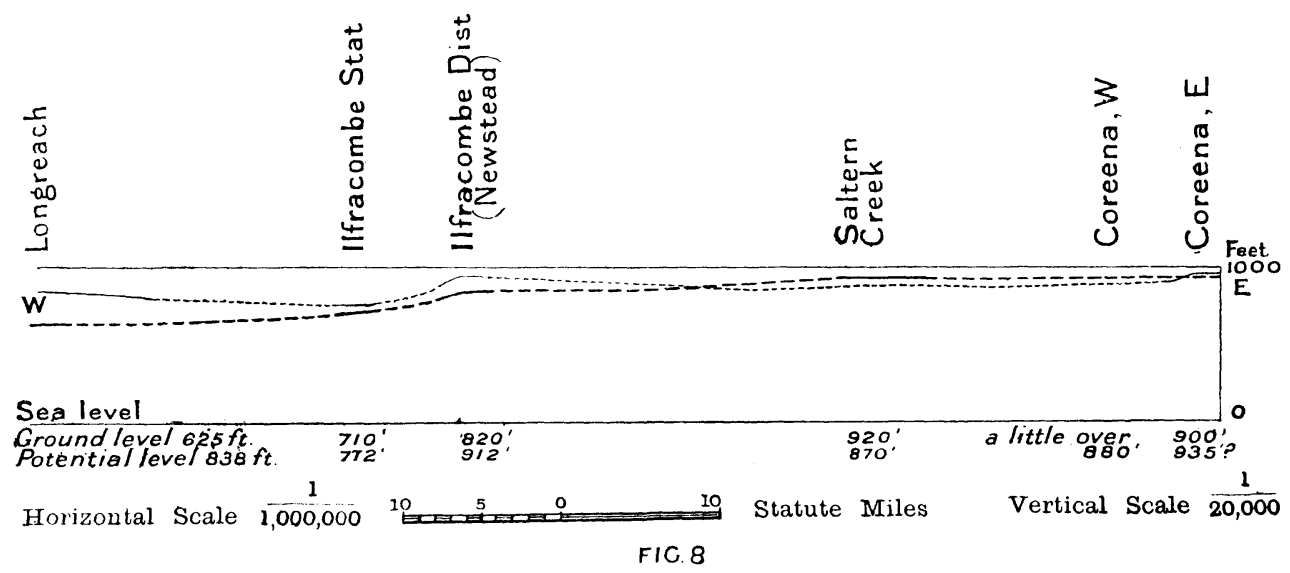

which is larger than all its other outcrops together, does not contribute to the flowing wells, and we are driven back to the smaller areas, 250 miles away, or to Jurassic sandstone 800 miles away, which are inadequate for the areas nearer them.

The Kynuna well can hardly receive its water from any of the more southern outcrops of the Blythesdale Braystone. The nearest of them are at Jericho and Aramac, where the water has a potential of only 800 feet ; and they are separated from Kynuna by an area with a potential of over 900 feet. The only area on the water-pressure theory in which to look for the source of the water would be that of high potential around Hughenden; but that area is covered by basalts with some Desert Sandstone. It is true that in Mr. Gibb Maitland's map † of 1898 some exposures of the Blythesdale Braystone are shown rising on the edge of the schists of the Cape gold-field to the height of 2198 feet; but those outcrops are assigned to the Desert Sandstone in the two latest geological maps of the

* Tables, 1908, p. 27.

$\uparrow$ A. Gibb Maitland, "The Delimination of the Artesian Water Area North of Hughenden,' Geol. Surv. Queensland, 1898. 
area, the Geological Sketchmap of Queensland, issued in 1905, and the Geological Map, issued by the Water Supply Department in 1908. The high level Braystones that might once have been appealed to for the supply of the Kynuna well, have been removed from the maps.

Again, in the district near Barcaldine, the wells show numerous instances of a rise in potential away from the intake, and of wells ceasing to flow while others nearer the intake continue their discharge. Thus, as is shown in Fig. 8, the potential rises from Saltern creek going westward to Ilfracombe, and again from Ilfracombe continuing westward to Longreach. The same phenomenon is shown in the section (Fig. 9) from Brisbane to Cunnamulla.

Another similar case is the steady increase of gradient on the south-western border of the area ; the water will only rise to about 300 feet a little north of the north-western corner of South Australia, while further to the southwest, at Goyder's Lagoon, 150 miles further from the supposed intake, the water will rise to 600 feet. In that area there is no Blythesdale Bray. stone, the country is lowlying, and the rainfall almost the scantiest in Australia; so that it appears idle to appeal to any existing local addition from the present rainfall.

The increase of potential to the west is in agreement with the greatly increased flow from many of the western wells; and, as was remarked to me by Mr. B. L. Schooley, the manager of the Intercolonial

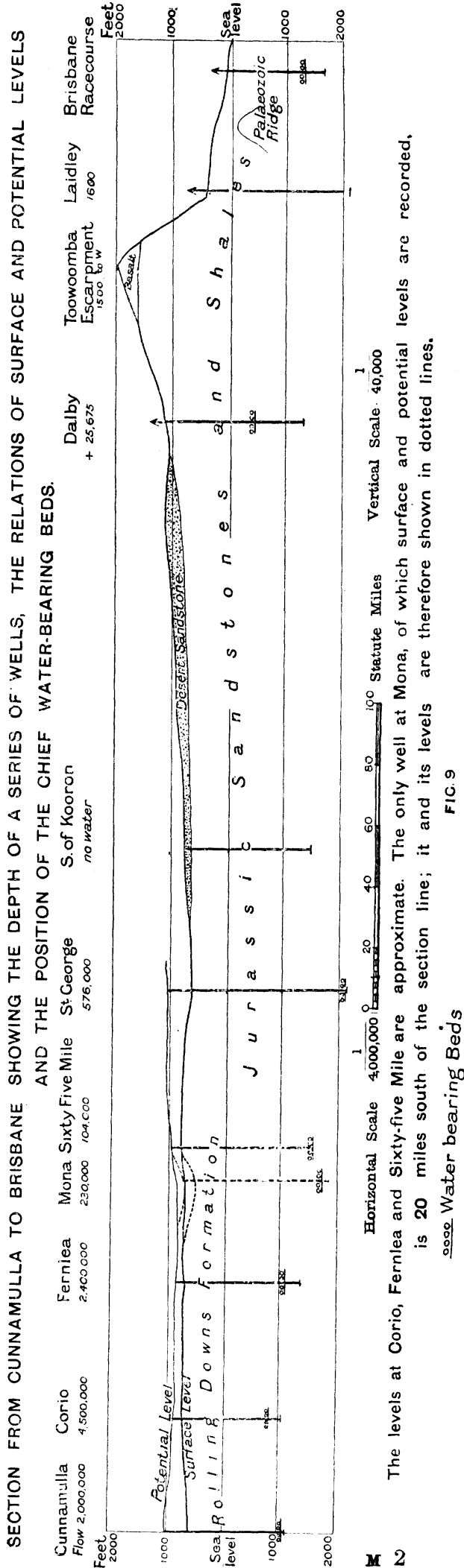


Deep Well Boring Company, the occurrence of many wells with enormous flows to the west of wells with much smaller flows is difficult to reconcile with the supposed flow from east to west.

Mr. Pittman makes no attempt to explain these anomalies except by remarking that the levels in Queensland have been determined only by aneroid, and are therefore so unreliable that no argument can be founded on them. Many of the wells, however, are situated beside the three railway lines which traverse Queensland from east to west, so that their heights are quite reliable; while the heights of the wells away from the railways were doubtless determined by reference to the nearest railway level. Full confidence may be felt as to the sufficient accuracy of the levels along the Queensland railway lines, and the irregular variation of pressures in wells of which the heights are reliable is sufficient to show that the water-pressure theory does not explain the facts.

The evidence obtained in the last five years confirms the isopotential lines previously drawn. For example, Mr. Schooley tells me that so far as his experience goes, the course of the isopotential lines, as shown in 1905, is correct. They will no doubt be modified in detail, especially in areas where wells are still few; but the fresh information confirms their substantial accuracy. Mr. Pittman remarks that the effort to use the isopotential lines is like fitting together the pieces of a picture puzzle. It is a picture puzzle in which, on the water-pressure theory, the pieces will not fit.

In the alternative theory of the flowing wells of Australia the pieces fit satisfactorily and the anomalies are readily explained. There are two high-pressure areas in Queensland on the north-eastern side of the area of flowing wells; and they are both areas of widespread volcanic activity in geologically recent times.* One of the high-pressure areas is to the north-west of Hughenden in a district where the geological surreys by W. H. Rands and A. Gibb Maitland have shown the existence not only of widespread sheets of basalt, but of ten extinct volcanic foci (see Fig. 10). $\dagger$

The second high-pressure area lies to the south-west of the basalts from Mount Hutton through the end of the Carnarvon Range, the Buckland Tableland and Mount Faraday to Mount Playfair. Some of the basaltic outliers to the southwest of this basalt tableland probably cover the vents of the old volcanoes. The high potential in these areas of former volcanic activity is a natural consequence of the higher temperature that may be expected in the subterranean waters.

The irregularity of the isopotential lines in Australia offers a most instructive contrast to those of South Dakota, as shown by Mr. Darton's map of that area, of which part is reproduced as Fig. 11. In Dakota, as would be expected on the water-pressure theory, the lines are regular and at right angles to the main direction of flow, and show a steady fall from the intake to the outlet. If the isopotential lines in eastern Australia were as consistent with the requirements of the hydrostatic theory, it would probably not be called in question.

The geological conditions and the loss of head in wells flowing from waterpressure are very different from those of Queensland. The case with the smallest

* The date of the basalts of the Darling Downs is represented on the official maps as Trias-Jura, from the asserted interstratification of the basalts with those rocks. Being impressed by their Cainozoic aspect, I asked Mr. B. Dunstan (the Government Geologist of Queensland) as to their age, and he informed me that they, in his opinion, overlie Cainozoic beds.

$\dagger$ Mr. Rands' map was issued in 1891. The number of volcanic foci is confirmed by Gibb Maitland's later r:ap of 1898, part of which is reproduced as Fig. 10. 
loss of head collected by Mr. Pittman is that of the St. Peter Sandstone in Wisconsin, and Kentucky, where it is 67 foot per mile. In these States, as in South Dakota, the conditions are most favourable to percolation. Thus, A. R. Schultz describes the St. Peter Sandstone in Wisconsin as a "soft incoherent rock, of large wellrounded grains of quartz;"* and this porous rock is interbedded between the magnesian limestone and the Galena-'Trenton limestone, which is 200 to 300 feet in thickness, and is traversed by many cracks and fissures. The account of the St.

GEOLOGY OF THE EASTERN MARGIN OF THE ARTESIAN AREA NEAR HUGHENDEN AFTER MAITLAND (1898) SHOWING THE DISTRIBUTION OF THE EXTINCT VOLCANIC VENTS IN THE AREA OF HIGH POTENTIAL. THE DESERT SANDSTONE IS EXTENDED IN THE S.E. CORNER OF THE MAP IN THE LATER GEOL SURVEY MAP OF QUEENSLAND.

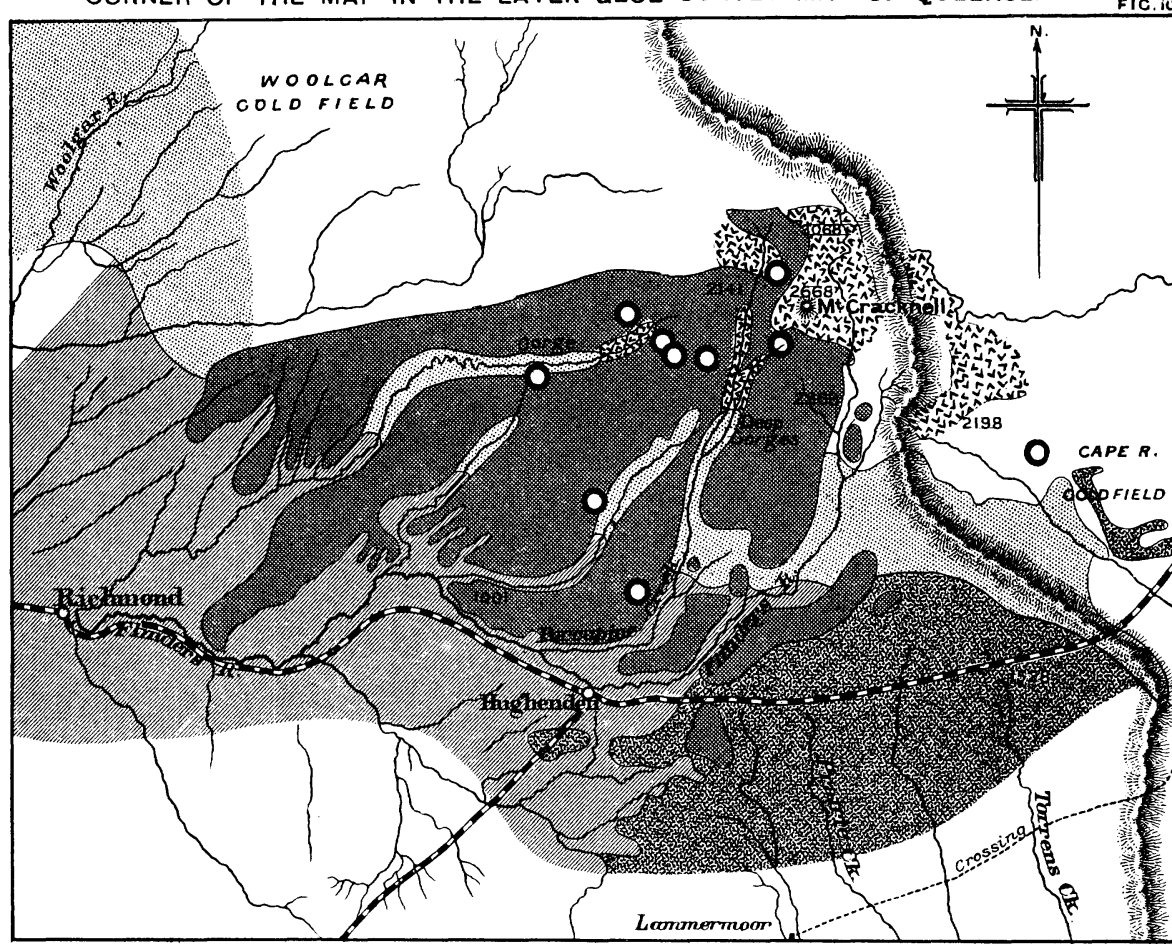

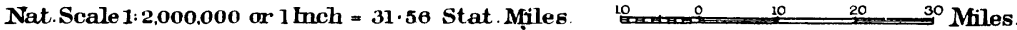

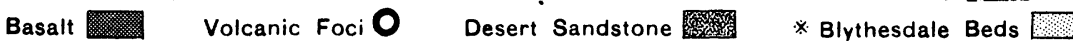
Rolling Downs Beds Wumln Granite or Felsite

* The later maps include all bat the outcrop in the N.W. corner in the Desert Sandstone

Peter Sandstone in other states, given in the same series of memoirs, shows that the St. Peter Sandstone retains these characters and conditions over a wide area. In Iowa it is described by W. H. Norton $\uparrow$ as "a bed of incoherent quartz sand, which, because of its freedom from clays and cementing material, and because of the phenomenal roundness of its grains is an exceptionally important water horizon." Its thickness is about 100 feet and in Iowa also it lies below the

* ' Underground Waters of Eastern United States.' U.S. Geol. Surv., Water-Supply Paper, No. 114, p. 236. 1905.

$\dagger$ Ibid., p. 223. 
porous Galena-Trenton limestone. The catchment area on the edge of this rock is described by Norton as of great width owing to its gentle dip.

Water percolating through loose porous rocks or flowing through wide channels or spaces, such as caves, large fissures or large joints, suffers but slight loss of head. In the London basin the head is maintained, not by water percolating through the actual chalk, but through fissures, and if a bore does not strike a fissure it fails. When a large supply is wanted from the chalk, a well is dug and galleries are driven from the bottom in order to expose a large collecting surface and strike many of the contributing fissures.

In Queensland the conditions governing the subterranean passage of water are different. It is usually admitted that the Blythesdale Braystone extends but a comparatively short distance westward, and that the water-bed may be either sand or sandstone interstratified with the clays of the Rolling Downs Formation;

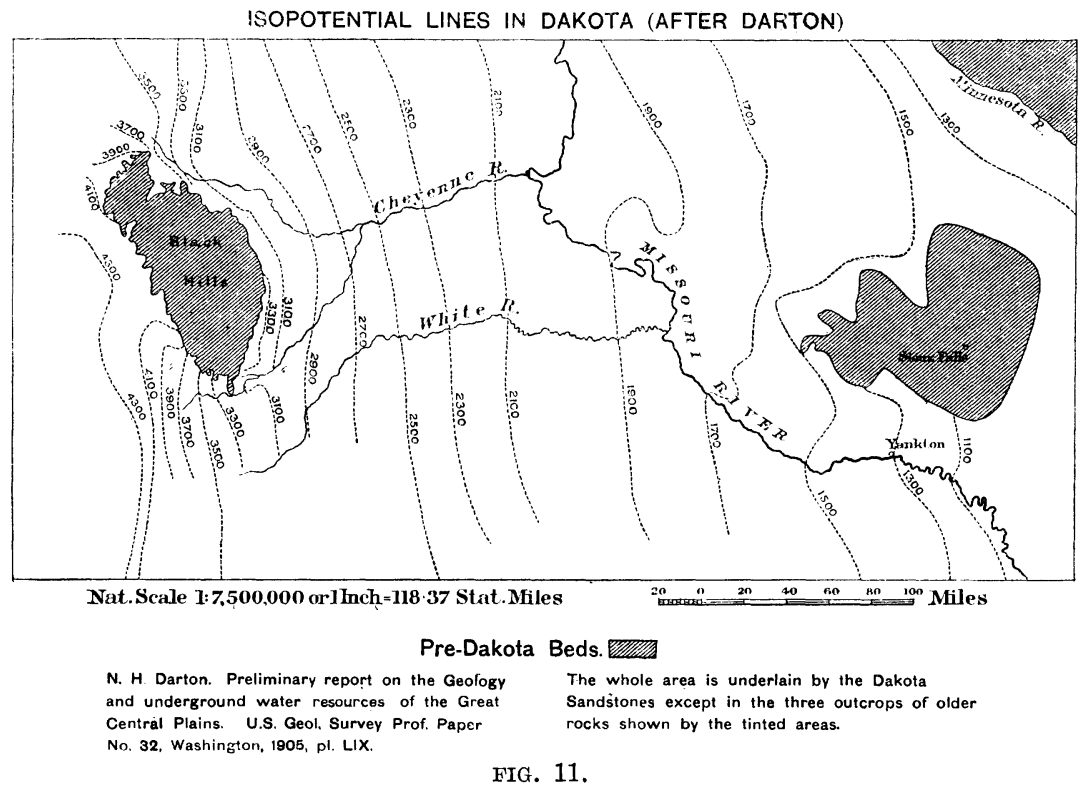

according to Mr. Pittman, in some cases the water comes from the Carboniferous rocks which have no high-level eastern intake area in Queensland. As Dr. Jack pointed out, the water must be flowing through the rock and not through fissiures, or more of the bores would have been barren. The bores occasionally find water in beds of quicksand or soft crumbly sandstone ; and the bore records show that some of the wells obtain their water from thin bands of sandstones, which have no very long horizontal extension. In South Dakota the water bearing layer is one vast sheet of sandstone. In Australia the water comes from thin disconnected seams of sandstone, which, it is obvious from the bore records, are not continuous from the wells to the eastern outcrop of the formation.

The flowing wells in Central Australia agree not with those of the simple type of South Dakota in which the upflow is due mainly to hydrostatic pressure, but with the more complex type in such areas as Idaho and south-eastern Oregon, the outflow of which, as Mr. I. C. Russell has shown, is due to subterranean heat. Mr. Russell has pointed out that the flowing wells in that basin discharge 
from water-bearing beds, which derive their supply partly by the percolation of meteoric water from the surface, and partly from hot waters which rise through fissures into the permeable beds (Fig. 12). Mr. Russell distinguishes the water from the two sources by their temperature.

Fig. 12

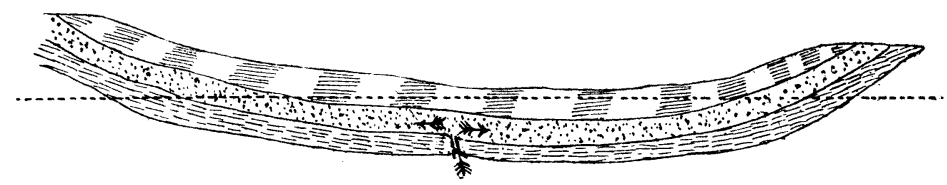

\section{Russell's Diagram of an Artestan Basin changed with water from Belaw.}

(c) The Toowoomba Sandstones as a High-pressure Reservoir.

The fall in potential level of the wells in south-western Queensland was explained by the early advocates of the water-pressure theory as due to the existence of an outlet to the Great Australian Bight, to which the water is flowing. Hence the loss of potential is the necessary deduction for hydraulic head. The assumed outlet to the Southern ocean has been universally abandoned, and Mr. Pittman has therefore to find another. Two outlets are possible, one to the Pacific near Brisbane, and the other to the Gulf of Carpentaria. The Brisbane outlet would be no use to Mr. Pittman's theory, and that there is no great discharge through it is shown by the small quantities of water in the Ipswich mines and the slight flow of 8000 gallons a day from the well, 1781 feet deep, at the Brisbane racecourse. Mr. Pittman has therefore to maintain a great discharge from south-western Queensland over the rim of old rocks below Manfred Downs into the Gulf of Carpentaria.

In order to maintain this flow he requires (1) a high-level collecting ground, which he assumes in the Jurassic sandstone (Trias-Jura) at Toowoomba ; (2) a powerful flow through those sandstones first westward and then northward, over the Manfred ridge; (3) the continuity of the water-bearing strata through this long and sinuous course.

The facts seem to me opposed to each of these requirements. There is no doubt a tract of land at Toowoomba reaching at one point to the height of nearly 2000 feet; but as has already been pointed out, the area of sandstones at this level is small, and the rocks are not well placed for a storage reservoir, since they are tapped on the east by the Toowoomba escarpment. We are not dependent on mere probabilities on this point, as two facts show that the Jurassic sandstone at Toowoomba do not act as a high-level pressure reservoir ; (1) the well in these sandstones at Dalby, to the west of Toowoomba, which has been bored through these sandstones to the depth of 2500 feet, yields a flow of only 25,675 gallons a day ; ${ }^{*}(2)$ and instead of the area to the west and south-west of Toowoomba being a high-pressure area, it is occupied by the largest gulf of low pressure in Queensland.

The small yield of the Dalby well and the dryness of the Jurassic sandstones in the well at Albilbah, show that the main supply to the prolific flowing wells further west, does not come from the Jurassic sandstones of Toowoomba.

Mr. Pittman's third requirement, the continuity of the water-bearing layer,

* 'Henderson's Tables,' p. 2. 1908. 
is disproved by an overwhelming mass of evidence. Thus the water-bearing bed at Muckadilla, according to Mr. Pittman (Clarke Lecture, pl. viii.), is "PermoCarboniferous" and not Jurassic. The Kynuna wells show that the water from the flowing wells is not derived from beds which outcrop on the assumed eastern intake; and this fact is also shown by wells which derive part of their supply from the old rocks which form the rim and floor of the artesian basin. Mr. Pittman confirms the fact that the water from the Oxton well is obtained from a fissure in the granite, but he suggests that it is derived from the overlying sandstone; and the well at Glenormiston, to the west of the artesian basin, obtains a good supply with the water-level standing only 4 feet below the surface,* although bored through the older Palæozoic rocks into granite. $\dagger$ The significance of these cases is that the water-even if meteoric in origindoes not pass through one continuous water-bearing layer as in a typical artesian basin, and the analogy with water under the steady pressure of a stream flowing between impermeable layers becomes inapplicable.

The flow over the northern rim of the artesian basin would have to be considerable $\ddagger$ to allow of any appreciable movement of the water in the central basin, for the central area of flowing wells is 1000 miles wide, and the outlet to the north is limited to a line of 150 miles long. Moreover, in central Queensland, the wells are fed from the depth of 3000 feet below sea-level, and in south-western Queensland and South Australia from 4500 feet below sea-level; yet the rim of the basin near Manfred Downs is less than 300 feet below sea-level.

Mr. Pittman has reproduced my section from the Gulf of Carpentaria to Charleville and continued it to the sea at Brisbane, in order to show that the intake areas near Toowoomba would supply sufficient pressure to maintain the circulation of the water in the deep central basin. The section, as thus extended, is reproduced as Fig. 13, with some additions and modifications in Mr. Pittman's part of it, viz. (1) the insertion of the Pickanjennie and Brisbane wells ; (2) the deepening of the Muckadilla well ; (3) the insertion of the basalts on the summit of the plateau near Toowoomba; § (4) the "Blythesdale Braystone," marked by Mr. Pittman in the Roma well has been connected to the outcrop of that formation shown on the Queensland survey map ; (5) a dotted line in Mr. Pittman's map at Toowoomba is apparently intended to represent the base of the "Triassic Sandstone"; I have added another line which seems to me to represent that position more correctly, showing its passage eastward to beneath sea-level. The older rocks outcrop in places around Brisbane, but the Jurassic (Trias-Jura) Sandstones are nevertheless represented on the Queensland survey map as having a continuous outcrop from Toowoomba to the sea.

* ' Henderson's Tables,' p. 19.1908.

$\dagger$ A section of the well is given by Jack, "Stratigraphical Notes on the Georgina Basin, with reference to the question of Artesian Water," Proc. R. Soc. Queenslanü, vol. 11, Part II. 1895. Separate copy, p. 2.

$\ddagger$ Although Professor David at that time accepted a southern outlet for the artesian basin, his view of the practically stagnant nature of the water in the central basin of southern Queensland may be inferred from his remark that " in its central portions, at all events, the basin behaves like a sealed basin, and the pressure of the water in the central portions of it is therefore probably more hydrostatic than hydraulic," T. W. E. David, "Notes on Artesian Water in New South Wales and Queensland," Part II. Journ. R. Soc. N. S. Wales, vol. 27, 1893, p. 427.

$\S$ Readers of Mr. Pittman's remarks, 'Clarke Lecture,' p. 127, on his section (pl. viii.) would infer that the summit of the highlands at Toowoomba is formed of the sandstones. 


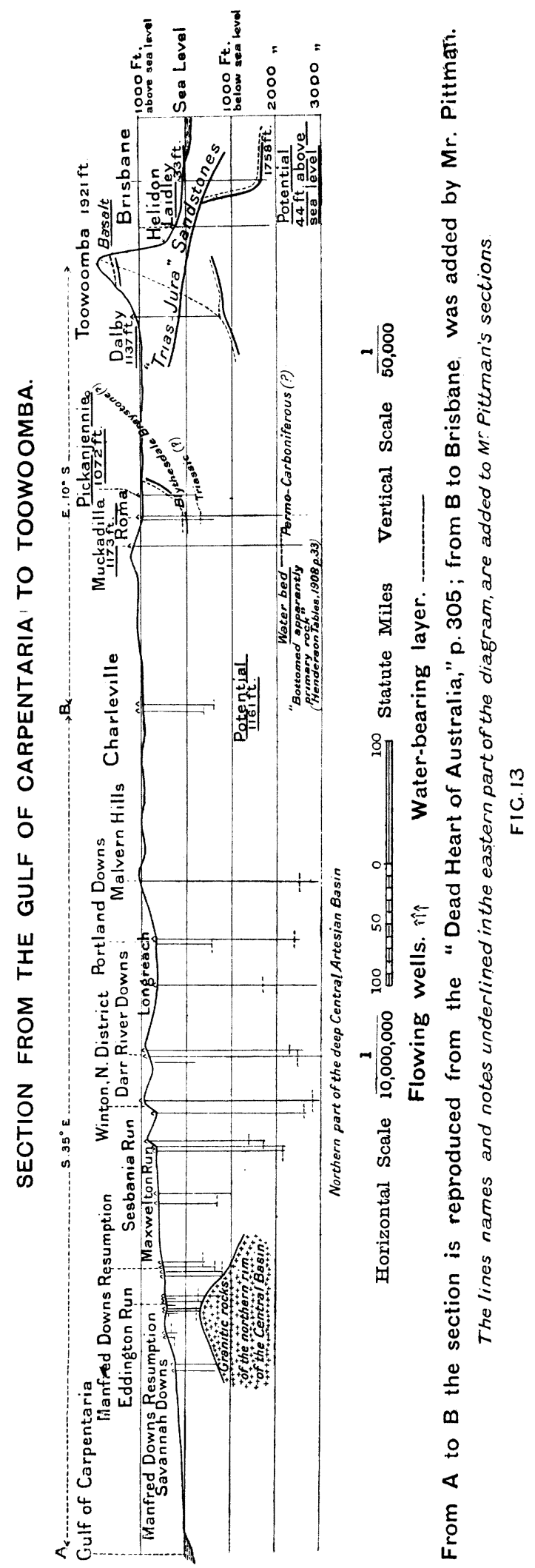

This content downloaded from 128.252.67.66 on Sun, 12 Jun 2016 06:11:55 UTC All use subject to http://about.jstor.org/terms 
Mr. Pittman's part of this section illustrates several interesting facts which do not help his theory that the water at Toowoomba exerts a high pressure on the water beneath Charleville, 350 miles away ; for the potential level at Charleville is $\mathbf{1 1 6 1}$ feet, and it is only 900 feet at a locality 100 miles from Toowoomba on the line along which the pressure should be exerted in order to influence the districts around and beyond Charleville.

Again, just east of Roma, according to the Queensland Geological Survey, there is an outcrop of the Blythesdale Braystone at a lower level than the ground at Charleville, where the potential level is 1167 feet ; and the potential of the well at Pickanjennie, 20 miles east of Roma, is only 1072 feet or 95 feet lower than it is at Charleville, which is $\mathbf{1 7 0}$ miles further down the hydraulic grade.

The upper part of the Pickanjennie well, according to the survey map, is in the Blythesdale Braystone,* which appears to contribute but little water to it, as the chief water-bearing bed is at the depth of 1420 feet, and therefore well within the Jurassic; and although the Dalby well, which goes through the whole of that formation, has the small flow of 25,675 gallons, the Pickanjennie well, which only enters the upper part of the formation, yields 177,680 gallons a day. The significance of this fact is that, in order to prevent the Jurassic sandstone draining through the Toowoomba escarpment and the Ipswich area eastward to the Pacific, it must be assumed that the formation is divided into water-tight layers by sheets of shale dipping westward. If so, the water bed of the Pickanjennie well would get its supply from only the western end of the Jurassic area, which, I understand, is at the level of only about 1200 feet above the sea. In that case any pressure exerted in the direction of the central basin from Toowoomba would have to pass well to the south of the Charleville-Dalby line and through the area of lowest potential.

\section{(d) Oscillating Wells.}

Another striking phenomenon in connection with these wells, for which the water-pressure theory gives no explanation, is their occasional tidal oscillation. The best known of these wells is at Urisino. Mr. Pittman placed a tide gauge on it, and his observations show that as the tidal period varied from time to time, the movement cannot be a lunar tide, as it is in many oscillating wells. $\dagger$

I duly considered the possibility of explaining the oscillation in the Urisino well by a wave action on a subterranean current producing a kind of water hammer; but no solution on that line seemed possible. I was therefore driven to the view that this interesting well was affected by variations in gas-pressure like a periodic geyser. Mr. Pittman rejects this explanation and has misunderstood my statement about the well, for he remarks ('Clarke Lecture,' p. 124) that " the suggestion made by Gregory that the phenomenon may be due to escape of

* The well section ('Henderson's Tables,' 1908, Well Section, No. 210) does not support this determination, and thus suggests a further reduction in the area of the Blythesdale Braystone. The bore passed through 404 feet of shale immediately between the surface deposits.

$\dagger$ Mr. Pittman says there is only one tidal well in New South Wales, and that the statement that the Ninety-one Mile Bore also shows tidal variations is a mistake caused by a confusion of localities, which his readers would infer was due to me. The statement that the Ninety-one Mile Well has a tidal rise of 4 feet every four hours I quoted from a published report by Professor David. In addition to Urisino, there are tidal wells in Queensland and others which increase in activity at irregular intervals. 
carbonic acid cannot be endorsed," and he goes on to say that there is no evidence there of carbonic dioxide. But I was careful to point out that "we do not know enough about the water in the Urisino well, for any reliable suggestion to be made as to the precise cause of its oscillations " ('Dead Heart of Australia,' p. 330). I suggested that the Urisino well " probably belongs to the same category as the well at Jaude," in which the movement is due to the escape of carbon dioxide. The oscillation at Urisino may be due to some other gas ; but that the well belongs to the same category as that at Jaude appears to be still the only explanation of its movements. Mr. Pittman offers no other. The water-hammer hypothesis, which might be reconciled with the hydraulic theory, appeared so inadequate and untenable that I did not think it worthy of mention.

In addition to this periodic movement, some of the wells show oscillations, which are probably due to a true tide or to variations in barometric pressure. Thus Mr. Graham Hewett* tells me that at Cunnamulla the well shows slight alterations in pressure, which are highest at full moon; they therefore, as he justly remarks, indicate a tide due to a lunar influence. The well at Boatman, I am told, flows most powerfully at midday; this increase may be due to the diurnal atmospheric tide. Mr. John Alexander, the headmaster of the school at Longreach, whose house is immediately opposite the bore, remarked to me that the well must vary in pressure, as its roaring is much louder at some times than at others. According to Mr. Henderson ('Tables,' 1908, Well Section, 208), one of the water-bearing beds in the Dalby well gives a "pulsatory flow."

Mr. W. E. Miller, manager of the Coreena station, has supplied me with an interesting record of a phenomenon at well 7 upon that station, which appears inexplicable on the water-pressure theory, but presents no difficulty if the flow be due to gas-pressure. The well was sunk in 1898, and for a time discharged 100,000 gallons a day. In 1900 the flow ceased after having been very small for some time; Mr. Miller dropped a stone down the well in order to determine the level of the water, which immediately began to flow again. The discharge continued for a month or so, and then stopped. Mr. Miller restarted it by lowering a piece of iron down the casing and pulling it up rapidly. For about a month he was able to start the well by repeating this operation once a week. Sometimes he could re-start the flow by striking the clamps with a heavy sledge hammer. In time all these methods ceased and the well is now pumped by a mill.

The flow of another well in the same district could be restarted by blowing down the bore. The restoration of flow by such slight disturbances of equilibrium can be more easily explained by a variation of gas-pressure, analogous to the eruptions of a geyser caused by throwing turf into it, than by a change in so steady an influence as water-pressure.

The Hon. E. W. Lamb kindly tells me that an increased flow has been observed in some of the wells of New South Wales at times of low barometric pressure. The increased flow from springs when the barometer is low is a well-known phenomenon which has been established, for example, by the work of Mr. Baldwin Latham, near Croydon. The increase is no doubt due to gas pressure, the gases dissolved in the water expanding when the atmospheric pressure is reduced. Mr. Latham's evidence therefore shows that gas-pressure acts even on wells, of which the flow is mainly determined by ordinary water-pressure.

* Letter, September 6, 1909. 


\section{The Causes of the Ascente of the Water.}

\section{(a) Gas Pressure.}

Though the hydrostatic pressure of adjacent water no doubt helps the ascent of water up the wells, the irregularities in the water-level and its oscillation show that other factors are also at work. One of the most important is gas-pressure, due to the tension of gases imprisoned in the heated water. The entrance of heated plutonic water into the water-bearing layers acts somewhat like the air in an air-lift pump, in which the expansion of compressed air forced into a well raises the water to the surface.*

Dissolved gas occurs in many of the Queensland flowing wells. Thus at Roma the gas evolved has been used for lighting the town. $\dagger$ Gas is discharged with the water of flowing wells in all parts of Queensland, as is shown by Mr. Henderson's tables; and various informants have added to the known range of gas-charged waters. Thus, Mr. J. T. Hannay told me that water from his wells at Geera at first appeared milky owing to the numerous gas-bubbles. Those wells are not discharging as abundantly now as they did, and the amount of gas evolved has diminished; but as I watched them, bubbles could be seen continually rising to the surface with the outflowing water. One of the three bores at Albilbah has proved a failure, although a sudden rush of water from it was announced as the beginning of a great flow; but as soon as the gas which was rising with the water had escaped, the flow ceased.

The ascent of oil in oil-wells was at first assigned by one school of geologists to hydrostatic pressure; but that view has been generally abandoned. The spouting and overflow of the oil is now attributed to gas-pressure; and this explanation will probably be admitted as the main factor in areas where water flows to the surface at temperatures approaching the boiling point.

I was interested to find how widely spread in Queensland faith in the gaspressure explanation has become. The water-pressure theory, I find, has been rejected, amongst others, by Sir Arthur Morgan, the Lieutenant-Governor of Queensland ; Dr. J.P. Thomson, secretary of the Geographical Society of Queensland; Mr. Fysh, the secretary of the Shire Council of Barcaldine, and by practical well-borers like Mr. Hannay. Mr. Hannay advocated the gas-pressure theory between 1899 and 1902, and urged the town council of Barcaldine to adopt a policy of water administration based upon that view. His prediction that the wells would steadily diminish in flow has been only too completely fulfilled. The upholders of the water-pressure theory, on the other hand, predicted that there was no reason to fear any serious decrease in the yield of the wells. Theories as well as trees may be judged by their fruits.

\section{(b) Rock Pressure.}

The second factor which I believe helps the ascent of the water to the surface through these wells is the weight of the overlying rocks. Mr. Pittman objects that the weight would prevent the entrance of the water into the bed; but this

* In air-lift pumps, according to some authorities, the effect is due to the lowering of the specific gravity of the water-column by the amount of air discharged into it.

$\uparrow$ Mr. Pittman endeavours to separate this well from the others by the view that it enters the Permo-Carboniferous rocks below the Jurassic sandstones. This identification is, however, rejected by Cameron of the Geological Survey of Queensland, an expert on the Carboniferous and Jurassic rocks of south-eastern Queensland. 
objection could at most only apply to the replenishment of the bed from its outcrop, and not to the inclusion of water at the formation of the bed, or to water injected into it from below.

Mr. Pittman also objects that rock-pressure would force the water from a water-bearing layer to escape along its outcrop; but the water would only escape there from that width of the bed wherein the resistance by friction to the movement of the water is less than the rock-pressure.

Mr. Pittman further objects to the efficiency of rock-pressure by an analogy with bricks in a wall. He remarks that the space left by the removal of a brick from the bottom of a wall is not filled by the bricks above being pressed downward into the cavity. But a brick wall erected on a sheet of waterlogged sand or soft clay would squeeze the plastic material away from beneath it. Every miner knows how clay on the floor of a tunnel rises slowly into it by the pressure of the walls. Is this movement due to the weight of the clay at the outcrop instead of to the weight of the adjacent rock ?

Mr. Pittman's main argument against the rock-pressure explanation is an appeal to American authorities, and he quotes a letter from Mr. M. L. Fuller, saying that rock-pressure, though often advocated, has never been supported by any real evidence, has never received official sanction or been accepted by careful investigators. Since the date of that letter, Mr. Fuller has written a memoir on the controlling factors of artesian wells, amongst which he includes rockpressure. Mr. Fuller, it should be remembered, limits the term artesian to wells in which the water rises by hydrostatic pressure. He would, therefore, refuse to accept as artesian any well flowing only by rock-pressure, which he, however, accepts as one of the various factors influencing the outflow from artesian wells. He says, for example, that "extensive sinkings of the ground have followed the pumping of water from mines and the withdrawal of the support afforded by hydrostatic pressure, indicating that the rock-pressure on the water must have been considerable, at least locally." *

Mr. Fuller adopts not only rock-pressure as an effective factor, but comparatively insignificant loads. Thus he describes the outflow from wells as affected by variations of barometric pressure and "still another result, which may be more common than is usually suspected, is the increase of pressure on confined waters, due to the plastic deformation of impervious beds under the varying loads resulting from changes in the water level of overlying streams, lakes, or the sea. This is especially noticeable in wells along the sea coast." $\dagger$

Other recent American authorities on water supply, such as Veatch, also accept rock-pressure as an important factor. He even considers that the weight of a city, which must be very small in comparison with that of a thousand feet of rock, aids the outflow of water from flowing wells. There would be no such effect when a city is built upon solid rock; but the weight of a city on a sheet of clay overlying water-bearing beds, as at New Orleans and Galveston, would, Mr. Veatch remarks, affect the outflow from the wells.

A striking instance of the raising of the water-level in a well by a small load is quoted by Veatch, $\ddagger$ from a record by King from Madison County, Wisconsin.

* Fuller, M. L., "Summary of the Controlling Factors of Artesian Flows," U.S. Geol. Surv., Bull No. 319, p. 33.1908.

$\dagger$ Ibid., p. 32.1908.

$\ddagger$ Veatch, A. C., " Fluctuations of the Water-Level in Wells, with Special Reference to Long Island, New York," U.S. Geol. Surv., Water-Supply and Irrigation Paper, No. 155, p. 75.1906. 
The water-level in a well 140 feet from a railway line is raised by the passing of a heavy freight train.

Hence, as the extra load on the earth's surface due to a shower of rain, a flood in a river, an increase in depth of a lake, or the passing of a heavy train, may increase the outflow from wells, it is idle to deny that the weight of several thousand feet of rock resting upon a waterlogged bed of sand or friable rock would not squeeze the water into a bore-hole. Subsidences of the surface caused by the pumping of subterranean water, show that such water is under pressure from the overlying rocks. It is quite true, as Mr. Fuller says, that rock-pressure may not be a very common cause of artesian wells, for the great majority of them derive their waters from shallow beds. But Mr. Fuller's memoir now shows that this factor has received official sanction and is accepted by careful investigators.

That rock-pressure must be a powerful factor in squeezing water out of layers of soft rocks, which are deeply buried under thick masses of overlying material, may be left to the common-sense judgment of geologists who have considered the large amount of pore space present in rocks on their first deposition. The proportion of pore spaces in clays and sands is high, and the interspaces in an aqueous rock are originally occupied by water which is gradually removed from the rock by drainage, by evaporation, or by the water being pressed out by the overlying material. As Sorby remarked,* rocks which contained as much as 90 per cent. of water " may have been made almost solid by the squeezing out of this water."

All aqueous rocks are at first charged with water, and they may retain some for a prolonged period. Thus the interesting work of Lane has shown that even Cambrian clays contain residual water, from which he has estimated the salinity of the Cambrian Sea. $\dagger$ The rocks gradually part with their original water, and may, during contraction, discharge several times their own final volume. If, as in the case of the Australian flowing wells, water-logged beds are covered by a heavy sheet of clay, the water may be retained in the water-logged beds until some artificial outlet be made. Then the rock-pressure inevitably squeezes out the water, either slowly, if the pressure be small in proportion to the strength of the water-bearing material, or rapidly, if the water-bearing rock yields easily to the pressure.

One of the Kynuna wells may be quoted to illustrate how especially favourable are the conditions in some of the Australian wells to the action of rock-pressure and unfavourable to hydrostatic pressure transmitted from a long distance. The mouth of this Kynuna well is at the height of 655 feet above sea-level ; its depth is 2221 feet; it has been bored through a variable series of shales, clays, sandstones, thin limestones, sand-rocks, etc.; though some of the beds of shale are thick and there is one 100 -feet seam of sandstone, the section of the well shows no less than eighty-eight strata. The carbonized wood in the sandstones, and the plastic, chocolate-coloured and variegated clays indicate that the beds are partly of terrestrial and fresh-water origin. Water enters the well from twenty-two thin bands of sand and sandstone (see Fig. 7, p. 161); some of these bands are 4, 6, and 8 feet thick, and some are apparently only a foot or two in thickness. The nearest outcrop of the assumed intake beds is at Saxby Downs, 120 miles away, and it is improbable that the thin water-bearing sandstones should extend so far. Many of them doubtless thin out within a short distance, so that water could only reach them from the Blythesdale Braystone by passing through the interstratified

* H. C. Sorby, Quart. Journ. Geol. Soc., vol. 64, p. 214.

$\dagger$ For example, A. C. Lane, "The Chemical Evolution of the Ocean," Journ. Geol. Chicago, vol. 14, pp. 221-225. 1906. 
beds of clay; and even if the water could ooze through the clay, the frictional resistance would completely absorb all the water-pressure. Even if the sandstones were continuous to the outcrop, the water passing through them would lose much head by friction, and as in this case Saxby Downs is lower than Kynuna, the water would have had no head to lose.

This Kynuna well gives, moreover, direct evidence that its flow is due to a local cause. The first water reached rose 40 feet in the well; the second water rose 80 feet ; the third 120 feet; the fourth 360 feet ; the fifth 560 feet; and this steady increase in the height to which the water rose in the well continued till the 22 nd contribution, from the depth of 2179 feet, rose 2246 feet, or to the height of 67 feet above the mouth of the well. The greater the depth of the waterbearing layer, i.e. the greater the pressure upon it from the overlying strata, the higher the water rises. The 2000 feet of strata pressing upon the thin beds of friable sandstone and sand squeeze out their water, just as clay in a mine is forced to flow into any tunnel cut through it.

It might be suggested that in such cases the deeper waters rise to a greater height because they entered the intake bed at a greater altitude. In the case of the Kynuna well we should have to assume that the water was taken in at many different intake beds, at such different levels that the water met with at the depth of 270 feet rises only 40 feet, whereas that from the depth of 1168 feet rises 560 feet, and the lowest water rises 2246 feet. The part of the Blythesdale Braystone area which might be supposed to feed this well may vary a few hundred feet in level; but there is no such variation in its surface as would be required to give such different pressures to these successive water-beds.

Moreover, according to the hydrostatic theory the intake bed which must supply the Kynuna wells is the northern outcrop of the Blythesdale Braystone or the Desert Sandstone overlying it. There can be no question in this case of the water coming from the Jurassic sandstones, as those rocks are not known outcropping in any position which can possibly collect rain water to feed the Kynuna wells.*

Mr. Cameron has given a section across this area and he represents the Blythesdale Braystone as one bed of very porous sandstone, $\nmid$ so that on the hydrostatic and hydraulic theories the water must percolate down through this bed of sandstone and then gradually spread through the thin layers of pre-cretaceous sandstone of the Kynuna well. This sheet of Blythesdale Braystone must act as a reservoir, which would equalize any difference in pressure from surface irregularities, and renders still more impossible of explanation why the water, if fed into the various sandstones of the Kynuna well from the Blythesdale Braystone, should be under such greatly different pressures.

The varying ascent of the Kynuna waters must have a local explanation, and the local rock pressure is quite adequate.

\section{The Chemical Composition of the Well Waters.}

On the water-pressure theory, as the water from the wells is derived from an eastern intake and is flowing westward, it would be expected that the water would become richer in dissolved materials on its passage to the west. As the

* The formation is not recorded in northern Queensland, although the discovery of Thinnfeldia in the beds marked as Desert Sandstone at Mount Mulligan on the Hopkinson Gold Field indicates their presence ; in this position they are too far east to supply the flowing wells.

$\dagger$ Ann. Prog. Rep. of the Queensland Geol. Surv. for the year 1900, pl. ii. 
Blythesdale Braystone is a rock of marine origin, the water percolating through it might be expected to show an increase in the amount of sodium chloride. As the Jurassic sandstone is, in part, at least, of terrestrial formation, the composition of its water might be more complex; but in either case a general increase in the mineral contents would be expected towards the west, since the water would have passed through more rock, and, owing to the increase of temperature with depth, would have greater solvent power. The chemical evidence, however, does not afford any convincing evidence in favour of the water-pressure theory. On the contrary, the chemical characters of the well waters are inconsistent with the simple westward movement of meteoric water. Thus, I showed in 1905, by a sketch-map of the salinities of the well waters, that crossing southern Queensland,* the eastern wells are richer in solid constituents than the central wells, and that the percentage of salts falls again toward the western margin of the basin. I referred also to the chemical analyses of a series of 13 wells on a line from east to west in New South Wales, and with the exception of the three last on the list, it is the second well in the series that is the most saline.

Mr. Pittman replies that the waters of 143 wells in Queensland are on the average less salt than those of the 14 in South Australia. Simple averages, however, are inadequate, for where the wells are shallow and the water is good, many wells are put down and the waters analyzed; where wells are deep and the water of inferior quality, fewer wells are bored. The best available data are the analyses of the Queensland wells, of which a long series is published in Mr. J. B. Henderson's tables of 1908.†. From these tables the map (p. 232) has been prepared, showing the variations in chemical composition of the Queensland well waters. The waters from rivers, springs, and shallow wells, given in Henderson's list of analyses, are excluded; so also are most of those from the deep wells outside the flowing well area, though a few are included for comparison; and some wells are omitted, as the analyses are said to be unreliable or the results given are inadequate. Where waters of neighbouring wells have been analyzed the results are averaged. A list of the analyses used is given in an appendix, and the facts are graphically stated on the map (p. 232), which indicates the volume of total solids and proportions of the chief constituents. This map shows that some of the most saline waters come from shallow wells or from those east of the basin of flowing wells ; or, as in the case of a well at Hughenden, actually from the supposed intake. The well at Dalby, an example of the waters found deep in the Jurassic sandstone near the eastern margin, is much richer in saline matters than water from the same beds which, on the waterpressure theory, has flowed through the rock for two or three hundred miles. At Winton the composition of two different waters is shown and the shallow water is by far the more saline, being specially rich in sodium and potassium chlorides. Comparison of the well waters in a series of lines across this map westward from the supposed intake beds shows that there is no regular increase of the saline constituents in the direction of the supposed flow. All the wells in one district may show a close resemblance, as in the south central part of the map ; whereas in the central area, as around Longreach and Bradley creek, the wells show exceptional variety.

This map gives no evidence of any subterranean streams of water slowly

* 'Dead Heart of Australia,' opp. p. 314.

† "Tables of Artesian Borings, Perennial Springs and Water Analyses," Queensland Water Supply Department, Brisbane, pp. 41-52. 1908. 
working westward through a continuous permeable layer. It is true that the waters of the wells in variable strata vary in chemical composition; but such variations are usually easily explained. Some cases may be due to adsorption; but I am not aware of any artesian waters from widespread sheets of the same rock, such as the chalk of the London basin and the sandstone of Dakota, that show such striking changes in composition as the Queensland wells. Thus, according to Darton, the water in the great artesian basin of Dakota, which Mr. Pittman compares with the Australian wells, shows some slight variations in chemical composition. The water in Dakota has flowed underground for at least 150 miles and is more or less saline in all the wells ; but, unlike the Australian waters, in only a few instances, says Darton, ${ }^{*}$ are the dissolved constituents sufficient in amount to affect the taste or general usefulness of the waters, which can be used for irrigation throughout the basin. Indeed, Darton's map $\dagger$ shows that the gardens irrigated with this water are most crowded in Miner County, on the eastern border of the artesian area, although the water there has had a subterranean passage of at least 250 miles. Darton $\ddagger$ gives a list of 23 analyses from the South Dakota wells and a map showing the distribution of the variations in composition; and the list includes no such striking differences as those of the wells of Central Australia. The Dakota waters all contain sodium choride, and 11 out of the 23 contain sodium carbonate; but in no case does the sodium carbonate exceed the sodium chloride. All the wells contain some calcium car. bonate and all but one sodium sulphate, of which the amount often exceeds the amount of chloride. The distribution in the total salinity is also generally regular. A well on the up stream side is the richest in salts, and the amount in a well to the west of Westport slightly exceeds that in the well to the east of that town; but the unusual salinity in these two wells is due to a great increase in the amount of sodium chloride, and can be easily explained, as Mr. Darton remarks, by some local variation in the rocks. The wells on the southern side of the basin along the course of the Missouri river are purer than those further to the north. Darton adequately explains this fact by the more rapid movement of the water through the especially porous sandstone near the southern margin, so that most of the salts there were leached out long ago ; in the area to the north the underground water is flowing more slowly, so that the salts have not been removed so quickly. This case offers a striking contrast to the distribu. tion of salinity in the Australian wells, in which the comparatively stagnant water in the central area is often the least saline, and wells on the line of the one admitted outlet are the saltest.

Reference to the chemical evidence renders it necessary to consider doubts thrown by Mr. Pittman on the reliability of the official analyses. He lays much stress on the fact that amongst a list of facts quoted as relating the Australian well waters to those of mineral springs is the recorded occurrence of 2.55 grains per gallon of zinc in a well at Toowoomba. This analysis (No. 86 of Henderson's Tables, 1908), according to Mr. Baillie Henderson, is one of those "made by the Queensland Government Analyst, Mr. J. Brownlie Henderson, and, during his absence in England, by his assistant, Mr. T. McCall." Mr. Pittman quotes a letter showing that the Government Analyst had been told, when the sample was sent to him, that the bore had a galvanized casing, in which the water had been

* N. H. Darton, 'Preliminary Report on Artesian Waters of a portion of the Dakotas,' 17th Ann. Rep. U. S. Geol. Surv. 1895 6, Part II., p. 677. 1896.

$\dagger$ Ibid., pl. ciii.

† Ibid., p. 677 and pl. ci.

No. IJ.-August, 1911.] 
standing; in spite of this warning, the presence of the zinc was recorded as one of the constituents. Some of the analyses in the tables are accompanied by the remark that owing to careless sampling or other cause, the analysis is unreliable. And in the absence of such warning in reference to the Toowoomba well, I naturally assumed that the one interesting fact stated about the sample was not due to casual pollution. The presence of zinc would not be proof of a plutonic origin, though it is a constituent of many mineral waters which are probably juvenile. It occurs, e.g., in the waters of Elizabethquelle at Kreuznach, of Karlsbad and Levico.*

Mr. Pittman also denies, on the evidence of the Government Analyst, the presence of lithium in the well water from Helidon Spa ; but the Queensland Government still continues to publish the occurrence of 2.68 grains to the gallon of lithium carbonate in that water, and last year the Helidon Spa water was still being sold with a label containing an analysis by Mr. W. A. Dixon, of Sydney, affirming the presence of the lithium, attached to each bottle. According to analyses by Mr. Brownlie Henderson (195 to 197 in the Queensland list), lithium is present in the springs at Herberton.

The chemical evidence to which Mr. Pittman devotes much attention I regarded as only of secondary value, for there is no chemical test applicable to these Australian well waters, which will certainly distinguish between a plutonic and a meteoric origin. I suggested that the analyses show that "much of the water is probably of plutonic origin " (p. 339), and on page 315 that the composition " suggests that much of it is derived from a plutonic source." But my argument from the chemical evidence as stated in the opening sentence of that section ('Dead Heart of Australia,' p. 312) was that " the chemical composition of the well waters does not afford any convincing evidence in favour of the artesian theory," and again (p. 339), " that the chemical composition of the well waters of Central Australia shows that there is no proof of any regular current in its subterranean waters from the north-east to the south-west." To that view I still adhere.

\section{Summary of Conclusions.}

The theory that a large area of water under high hydraulic or hydrostatic pressure lay under East-Central Australia was, in the first place, assumed to explain the low discharge of the Darling; but the view that the volume of that river is reduced by great subterranean percolation is shown by Mr. Kenyon's letter to have been based on exaggerated estimates and may be dismissed as unnecessary. Secondly, it was claimed that the assumed percolation may be actually seen to happen where large rivers and streams cross the outcrop of the Blythesdale Braystone; but the maps of the Geological Survey of Queensland show that the streams which flow on to the Blythesdale Braystone drain insignificant collecting grounds, and suggest that this formation discharges more water in springs than it absorbs from the streams that flow on to it. Moreover, the Blythesdale Braystone has been found to have only scattered outcrops instead of the long continuous outcrop originally believed; and the view that the Jurassic (or Trias-Jura) sandstones are the intake beds is untenable for Queensland for the following reasons - - (1) the only outcrops of that formation which could supply the artesian wells are confined to south-eastern Queensland ; (2) the rocks are drained by many

* A. Albu and C. Neuberg, 'Physiologie und Pathologie des Mineralstoffwechsels,' Berlin, 1906. P. 252, Table IV. ; p. 251, Table III. 
rivers which flow directly eastward to the Pacific ; $(3)$ that this formation is not heavily charged with water is shown by the evidence of the mines east of Toowoomba, and of the well at Dalby ; and (4) the part of the artesian basin nearest to these sandstones is a low pressure area and cannot transmit high pressure to the areas farther away.

There is no evidence of any great percolation of water from the surface at the present day under the area of the flowing wells, for the assumed intake bedsthe Blythesdale Braystones and the Jurassic (Trias-Jura) sandstones-are inadequate in area and have outcrops from which the water could escape at levels below the potentials of the wells.

The explanation that these wells maintain their flow in obedience to the principle that water finds its own level is contradicted by the irregularities in level to which their waters rise. This is shown by individual wells, such as those at Charleville and Kynuna, and in series of wells, such as those from Barcaldine and Longreach, in which sections show that the levels are irregular and the hydraulic gradient in places rises away from the assumed intake bed.

This feature of the wells, which is fatal to the water-pressure theories, is shown by the isopotential maps to occur in many parts of the area, as in the district of rising potential to the north of Lake Eyre. The essential accuracy of the isopotential maps has been confirmed by subsequent work.

Mr. Pittman's view that the water absorbed by the Jurassic sandstone near Toowoomba transmits a high pressure south-westward is opposed to the fact that in that direction is an area of low potential.

The theory that these wells are fed by modern rain water finding its own level does not explain the high temperature of the water from many of the wells, which is higher than that which I. C. Russell takes as clear evidence of a deep-seated origin. Neither does it explain the chemical distribution of the salts in these waters nor their periodic oscillation at non-lunar periods. The explanation that these periodic oscillations are analogous to periodic geysers has been reasserted by American authorities.

I accordingly hold that though water-pressure inevitably has some share in the ascent of the waters, the main factors are gas-pressure and rock-pressure. These are acknowledged as contributing factors in many areas of flowing wells; but in the great basin of East Central Australia they are the more important, and are to be regarded as the primary and not the secondary factors.

I therefore emphatically reaffirm the opinion that these wells are not maintained by an existing inflow of rain water and that this view was based on an erroneous analogy ; and accordingly that the waste of water which was defended upon that view is deplorable and should be stopped as soon as possible.

There is, fortunately, no fear of the complete exhaustion of this water supply. After the wells have ceased to flow, their water can be obtained by pumping. The stoppage of the automatic discharge will lessen the waste of water, so that the decline of the water-level will become slower. Water, though in more limited quantity, could be raised to the surface artificially, but the greater the present waste, the sooner will it be necessary to incur the cost of pumping to obtain a supply. 


\section{APPENDIX I.}

analyses of Queenslajid Well Waters used in Fig. 14.

Grains per Gallon.

\begin{tabular}{|c|c|c|c|c|c|c|c|c|c|}
\hline & & & $\mid \begin{array}{l}\text { No. of } \\
\text { bores. }\end{array}$ & $\begin{array}{l}\text { Total } \\
\text { solids. }\end{array}$ & $\mathrm{CaCO}_{3}$. & $\mathrm{MgCO}_{3}$ & $\mathrm{Na}_{2} \mathrm{CO}_{3}$ & $\mathrm{NaCl}$. & $\mathrm{KCl}$. \\
\hline Aberfoyle ... & $\cdots$ & $\ldots$ & 1 & 21.18 & 1.14 & - & $7 \cdot 3$ & \multicolumn{2}{|c|}{10.82} \\
\hline Adavale $\ldots$ & $\cdots$ & $\cdots$ & 1 & $88 \cdot 7$ & $\begin{array}{l}0.7 \\
9.8\end{array}$ & $\begin{array}{l}0.2 \\
4.2\end{array}$ & $63 \cdot 59$ & $\begin{array}{c}21.78 \\
7.6\end{array}$ & - \\
\hline $\begin{array}{l}\text { Afton downs } \\
\text { Ambo } \quad \ldots\end{array}$ & $\begin{array}{l}\ldots \\
\ldots\end{array}$ & $\cdots$ & $\begin{array}{l}5 \\
1\end{array}$ & $\begin{array}{r}30.7 \\
142.0\end{array}$ & $\begin{array}{l}2 \cdot 8 \\
1.6\end{array}$ & $\begin{array}{l}4.2 \\
1.0\end{array}$ & $\begin{array}{r}7.0 \\
89.4\end{array}$ & $\begin{array}{r}7.6 \\
45.9\end{array}$ & $\overline{-}$ \\
\hline $\begin{array}{ll}\text { Ambo } & \ldots \\
\text { Aramac } & \ldots\end{array}$ & $\begin{array}{l}\cdots \\
\cdots\end{array}$ & $\begin{array}{l}\cdots \\
\cdots\end{array}$ & 1 & 21.8 & 2.6 & - & $\begin{array}{l}89 \cdot 4 \\
10 \cdot 1\end{array}$ & $\begin{array}{r}4.9 \\
6.1\end{array}$ & 二 \\
\hline Avondale ... & $\ldots$ & $\ldots$ & 1 & $33 \cdot 0$ & 1.8 & 1.9 & $16 \cdot 3$ & 9.0 & - \\
\hline Bando $\ldots$ & $\ldots$ & $\ldots$ & 2 & 26.5 & 1.15 & 1.05 & 14.9 & 6.5 & - \\
\hline Barcaldine & $\ldots$ & $\ldots$ & 2 & 65.1 & $\overline{0}$ & - & 65.1 & - & - \\
\hline Beaudesert & $\cdots$ & $\ldots$ & 4 & $50 \cdot 0$ & 0.8 & - & $33 \cdot 2$ & $12 \cdot 2$ & - \\
\hline Beechal $\quad \ldots$ & $\ldots$ & $\ldots$ & 2 & 27.7 & $2 \cdot 0$ & 0.2 & $17 \cdot 0$ & $5 \cdot 3$ & - \\
\hline Blackall ... & $\cdots$ & $\ldots$ & 4 & 44.1 & 0.8 & $0 \cdot 2$ & 34.4 & $6 \cdot 4$ & - \\
\hline Boatman ... & $\ldots$ & $\ldots$ & 1 & 34.1 & 0.89 & trace & - & 11.12 & - \\
\hline Bowen downs & $\ldots$ & $\ldots$ & 4 & & say 8.0 & - & - & 9.0 & - \\
\hline Bradley creek & $\ldots$ & $\ldots$ & 1 & $235 \cdot 4$ & 14.5 & - & - & \multicolumn{2}{|c|}{$\overline{132} \cdot 0$} \\
\hline Brighton downs & $\ldots$ & $\ldots$ & 2 & 43.5 & $1 \cdot 1$ & $0 \cdot 4$ & 29.6 & 8.2 & - \\
\hline Brisbane racecour & arse & $\cdots$ & 1 & $113 \cdot 4$ & - & - & & say 58.0 & \\
\hline Brixton $\quad \ldots$ & $\ldots$ & $\ldots$ & 1 & 83.5 & 1.04 & trace & \multicolumn{3}{|c|}{81.42} \\
\hline Bunda Bunda & $\ldots$ & $\ldots$ & 4 & 25.5 & 0.75 & - & $18 \cdot 2$ & $4 \cdot 4$ & - \\
\hline Burenda $\quad .$. & $\ldots$ & $\ldots$ & 5 & 21.5 & 0.7 & 0.6 & 8.5 & $7 \cdot 4$ & - \\
\hline $\begin{array}{ll}\text { Caiwarra } & \ldots\end{array}$ & $\ldots$ & $\ldots$ & 2 & $4 \mathrm{C} .9$ & 1.0 & 0.4 & $22 \cdot 1$ & 12.0 & - \\
\hline Cambridge downs & & $\ldots$ & 3 & $24 \cdot 0$ & $2 \cdot 2$ & $2 \cdot 6$ & $10 \cdot 3$ & $3 \cdot 8$ & - \\
\hline Camooweal & $\ldots$ & $\ldots$ & 4 & $51 \cdot 6$ & $6 \cdot 3$ & 6.7 & 8.5 & $2 \cdot 8$ & - \\
\hline Charleville & $\ldots$ & $\ldots$ & 2 & $64 \cdot 3$ & 0.6 & - & $37 \cdot 4$ & 20.9 & - \\
\hline Claverton ... & $\ldots$ & $\ldots$ & $3^{*}$ & $42 \cdot 1$ & 1.3 & $0 \cdot 25$ & $26 \cdot 3$ & 11.6 & - \\
\hline Cunnamulla & $\ldots$ & $\ldots$ & 4 & $30 \cdot 7$ & 0.6 & 0.11 & 22.7 & $5 \cdot 7$ & - \\
\hline Dagworth & $\ldots$ & $\ldots$ & 1 & $28 \cdot 6$ & 1.9 & 1.3 & 17.4 & $3 \cdot 7$ & - \\
\hline Dalby . & $\ldots$ & $\ldots$ & 2 & $120 \cdot 7$ & 0.5 & 0.2 & 66.0 & $51 \cdot 0$ & - \\
\hline Dalgonally & $\ldots$ & $\ldots$ & 4 & $36 \cdot 0$ & 1.6 & 0.5 & 18.4 & 13.3 & - \\
\hline Darr River downs & & $\ldots$ & 1 & $53 \cdot 0$ & 1.6 & trace & 36.6 & 11.5 & - \\
\hline Dillalah $\quad \ldots$ & $\ldots$ & $\ldots$ & 3 & $72 \cdot 1$ & 1.8 & - & $34.0 *$ & $13.0 *$ & -- \\
\hline Eddington & $\ldots$ & $\ldots$ & 5 & $25 \cdot 3$ & 0.5 & 0.25 & 16.5 & $5 \cdot 1$ & - \\
\hline Elverston ... & $\ldots$ & $\ldots$ & 1 & $45 \cdot 3$ & 1.57 & trace & 23.3 & $13 \cdot 9$ & - \\
\hline Eulolo & $\ldots$ & $\ldots$ & 2 & 25.5 & 1.5 & - & 17.4 & 3.7 & - \\
\hline Fort Constantine & & $\ldots$ & 3 & 57.3 & 1.1 & - & 41.4 & $13 \cdot 0$ & - \\
\hline Hamilton downs & & $\ldots$ & 1 & 26.9 & $3 \cdot 8$ & 1.7 & 9.1 & 7.7 & -- \\
\hline $\begin{array}{l}\text { Hughenden Nos. } \\
273 \quad \ldots\end{array}$ & $\begin{array}{l}127,1 \\
\ldots\end{array}$ & $\begin{array}{r}175, \\
\ldots\end{array}$ & 3 & 29.1 & $8 \cdot 2$ & $10 \cdot 7$ & 1.7 & $5 \cdot 0$ & 二 \\
\hline Hughenden No. 2 & 204 & $\ldots$ & 1 & $281 \cdot 6$ & $45 \cdot 7$ & 6.86 & $65 \cdot 24$ & \multicolumn{2}{|c|}{51.94} \\
\hline Kynuna $\quad \ldots$ & & $\ldots$ & 1 & $26 \cdot 4$ & $2 \cdot 2$ & - & $16 \cdot 19$ & $\widetilde{5 \cdot 11}$ & $\overline{-}$ \\
\hline Laidley .... & $\cdots$ & $\ldots$ & 1 & 622.3 & & $\overline{\text { trace }}$ & & say 9.0 & - \\
\hline $\begin{array}{l}\text { Llanrheidol } \\
\text { Longreach }\end{array}$ & $\ldots$ & $\begin{array}{l}\ldots \\
\ldots\end{array}$ & $\begin{array}{l}1 \\
1\end{array}$ & $\begin{array}{l}30 \cdot 0 \\
80 \cdot 8\end{array}$ & $\begin{array}{l}2.5 \\
0.9\end{array}$ & trace & $\begin{array}{l}15 \cdot 0 \\
61.4\end{array}$ & $\begin{array}{r}6.9 \\
13.8\end{array}$ & 二 \\
\hline Lucknow ... & $\begin{array}{l}\cdots \\
\ldots\end{array}$ & $\cdots$ & 1 & 32.0 & 1.2 & trace & 19.9 & 6.7 & - \\
\hline Manfred downs & $\ldots$ & $\ldots$ & 8 & $26 \cdot 6$ & 1.5 & - & $16 \cdot 0$ & 7.8 & - \\
\hline Maria creek & $\ldots$ & $\ldots$ & 1 & 864.5 & 15.2 & 45.45 & $576 \cdot 0$ & 223.85 & - \\
\hline McKinlay . & $\ldots$ & $\ldots$ & 1 & $42 \cdot 1$ & 1.18 & - & 26.5 & 7.86 & - \\
\hline Millungera & $\ldots$ & $\ldots$ & 1 & 26.0 & 1.4 & - & 15.4 & 4.9 & - \\
\hline Morven & $\ldots$ & $\ldots$ & 2 & 16.9 & 1.2 & $1 \cdot 3$ & $9 . \overline{5}$ & 1.5 & - \\
\hline Mount Cornish, I & Dots & & 1 & 23.9 & - & - & 20.4 & $3 \cdot 4$ & - \\
\hline
\end{tabular}

* One of these bores has the alkaline constituents calculated from the notes given with the incomplete analysis; the quantities given in that bore include a large amount of $\mathrm{K}_{2} \mathrm{CO}_{3}$ and $\mathrm{KCl}$. 


\begin{tabular}{|c|c|c|c|c|c|c|c|c|c|}
\hline & & & $\begin{array}{l}\text { No. of } \\
\text { bores. }\end{array}$ & $\begin{array}{l}\text { Total } \\
\text { solids. }\end{array}$ & $\mathrm{CaCO}_{3}$ & $\mathrm{MgCO}_{3}$. & $\mathrm{Na}_{2} \mathrm{CO}_{3}$ & $\mathrm{NaCl}$. & $\mathbf{K C l}$. \\
\hline Mount Morris & $\ldots$ & $\ldots$ & 1 & $81 \cdot 0$ & - & 0.4 & $46 \cdot 3$ & $20 \cdot 7$ & - \\
\hline Muckadilla & $\ldots$ & $\ldots$ & 1 & $32 \cdot 8$ & $3 \cdot 3$ & 1.5 & $15 \cdot 9$ & $6 \cdot 9$ & - \\
\hline Murweh $\quad \ldots$ & $\ldots$ & $\ldots$ & 4 & 55.5 & 1.6 & 0.4 & 29.5 & $18 \cdot 1$ & - \\
\hline Normanton & $\ldots$ & $\ldots$ & 2 & $275 \cdot 7$ & - & - & $160 \cdot 0$ & $115 \cdot 9$ & - \\
\hline Offham $\quad \ldots$ & $\ldots$ & $\cdots$ & 1 & $41 \cdot 0$ & 1.4 & 1.0 & 29.2 & $7 \cdot 2$ & - \\
\hline Prairie $\quad \ldots$ & $\ldots$ & $\ldots$ & 1 & 58.0 & $3 \cdot 4$ & 1.7 & $15 \cdot 1$ & 34.9 & - \\
\hline Quambeytook & $\ldots$ & $\cdots$ & 1 & $25 \cdot 6$ & $3 \cdot 24$ & 1.4 & $10 \cdot 6$ & $7 \cdot 75$ & - \\
\hline Roma $\quad \ldots$ & $\ldots$ & $\cdots$ & 4 & 51.8 & 0.9 & 0.5 & $29 \cdot 0$ & $13 \cdot 0$ & - \\
\hline Saxby & $\cdots$ & $\cdots$ & 2 & $25 \cdot 3$ & 0.8 & 0.8 & 13.4 & $5 \cdot 7$ & - \\
\hline Sixty-five Mile & $\ldots$ & $\ldots$ & $\overline{1}$ & 70.12 & - & - & 48.7 & - & $9 \cdot 8$ \\
\hline St. George & $\cdots$ & $\cdots$ & 1 & 72.0 & 0.8 & $0 \cdot 2$ & $44 \cdot 4$ & $22 \cdot 2$ & - \\
\hline Tambo $\quad .$. & $\cdots$ & $\cdots$ & 1 & $40 \cdot 6$ & - & - & - & - & - \\
\hline Telemon $\ldots$ & $\cdots$ & $\cdots$ & 5 & $26 \cdot 8$ & $3 \cdot 9$ & $5 \cdot 2$ & $7 \cdot 2$ & 7.0 & - \\
\hline Thargomindah & $\ldots$ & $\ldots$ & 1 & $56 \cdot 0$ & - & - & $46 \cdot 8$ & $9 \cdot 2$ & - \\
\hline Tinnenburra & $\ldots$ & $\ldots$ & 8 & $35 \cdot 1$ & 0.7 & - & 21.2 & 8.9 & - \\
\hline Toolebuc ... & $\ldots$ & $\ldots$ & 1 & 52.9 & 1.2 & trace & 36.0 & $14 \cdot 2$ & - \\
\hline Warbrecan & $\cdots$ & $\cdots$ & 1 & 150.0 & - & - & - & $20 \cdot 0$ & - \\
\hline Warenda ... & $\cdots$ & $\cdots$ & 5 & 46.0 & 0.3 & - & $28 \cdot 2$ & $10 \cdot 7$ & - \\
\hline Westland statio & & $\ldots$ & 1 & $98 \cdot 0$ & $3 \cdot 0$ & - & $62 \cdot 6$ & \multicolumn{2}{|c|}{$15 \cdot 23$} \\
\hline Winton (deep) & $\ldots$ & $\ldots$ & 1 & $25 \cdot 0$ & $2 \cdot 7$ & trace & $8 \cdot 1$ & $4 \cdot 28$ & - \\
\hline Winton (shallov & & $\ldots$ & 1 & 219.8 & $9 \cdot 43$ & - & - & \multicolumn{2}{|c|}{$196 \cdot 2$} \\
\hline Woolerina ... & $\ldots$ & $\ldots$ & 1 & $206 \cdot 0$ & - & - & $57 \cdot 6$ & $\begin{array}{l}{[28.0} \\
17.0 \mathrm{Cl} .]\end{array}$ & - \\
\hline
\end{tabular}

\section{RECENT PROGRESS IN GEODESY.*}

By ARTHUR R. HINKS, M.A., Chief Assistant, Cambridge Observatory, and R.G.S. Lecturer in Surveying, Cambridge.

WrTHIN the last few years geodesy has made remarkable progress in many directions. My object in bringing some of them before you this afternoon is twofold. In the first place, it may be useful to bring together some of the facts which are scattered up and down in the rather inaccessible literature of geodesy ; in the second, I would invite discussion on the question whether an effort should be made to promote a gravity survey of Great Britain, of the latest pattern.

I. Base Measurements. - The whole art of base measurement was revolutionized by the discovery of Jäderin that long wires suspended under a constant tension in a horizontal catenary kept their length with remarkable accuracy, and by the subsequent use of the nickel-steel alloy "invar" in the manufacture of the wires or ribbons. The use of these wires is now almost universal-I believe that only the French geodesists have any serious doubts as to their value - and it is unnecessary to describe the ordinary manner of their use, other than by some photographs of the Spitsbergen and Semliki base measurements, which I owe to the kindness of Dr. Backlund and of Captain Jack, R.E. Experience seems to have shown that by the use of this apparatus we may gain the following important advantages:-

(a) Bases may be measured in places where it was formerly impossible to do so ; in Scotland, for example, that country which General Roy described as "so very inaccessible by nature." A base was measured in Scotland last summer by the Ordnance Survey, which is, one may hope, the preliminary to a most interesting inquiry into the accuracy of the primary triangulation of this country.

* Research Department, April 27, 1911. 


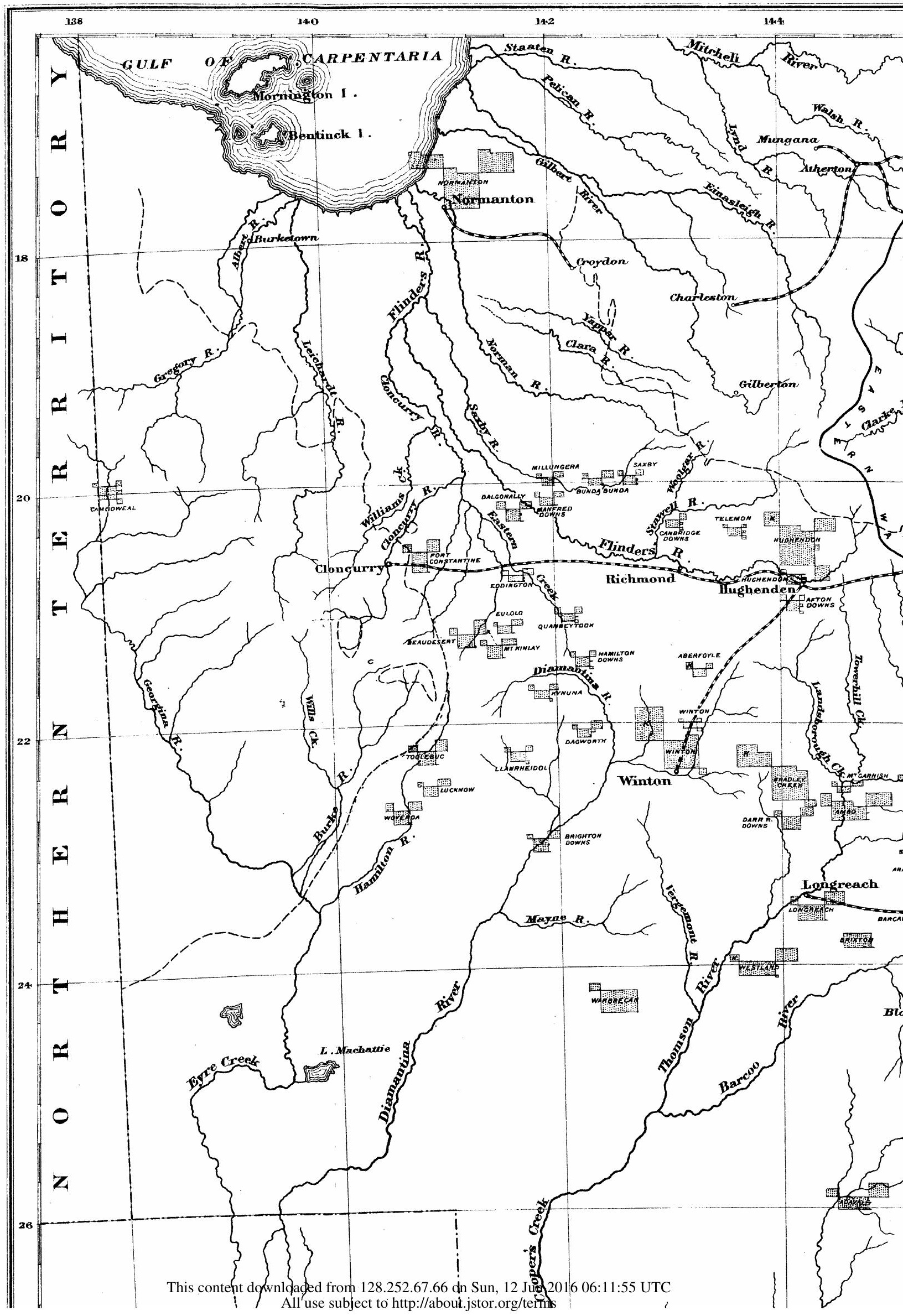




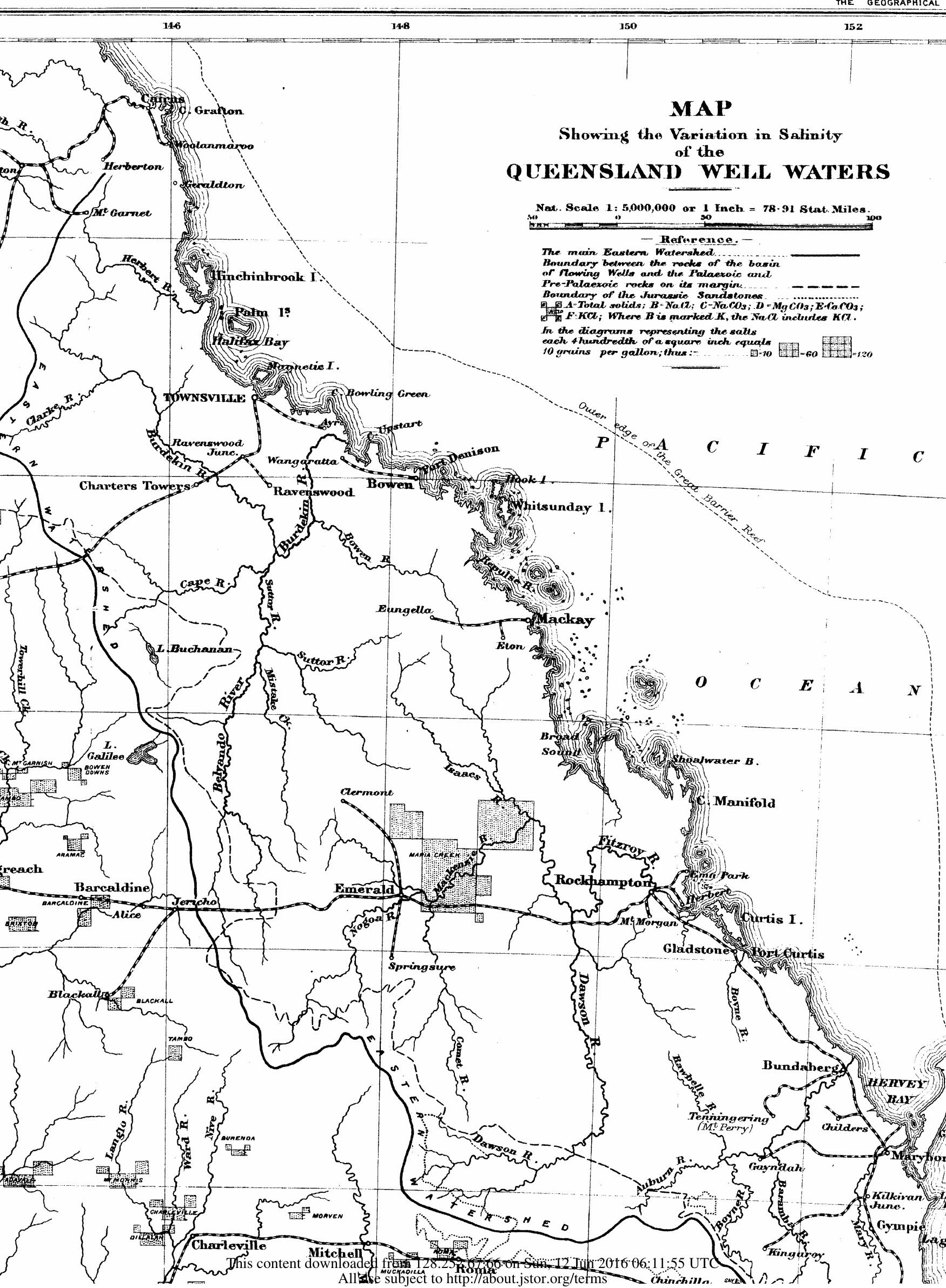




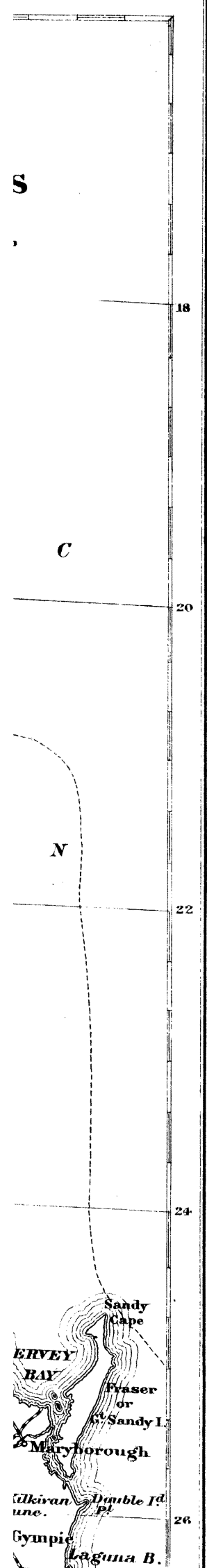

This content downloaded from 128.252.67.66 on Sun, 12 Jun 2016 06:11:55 UTC All use subject to http://labout.jstor.org/terms 


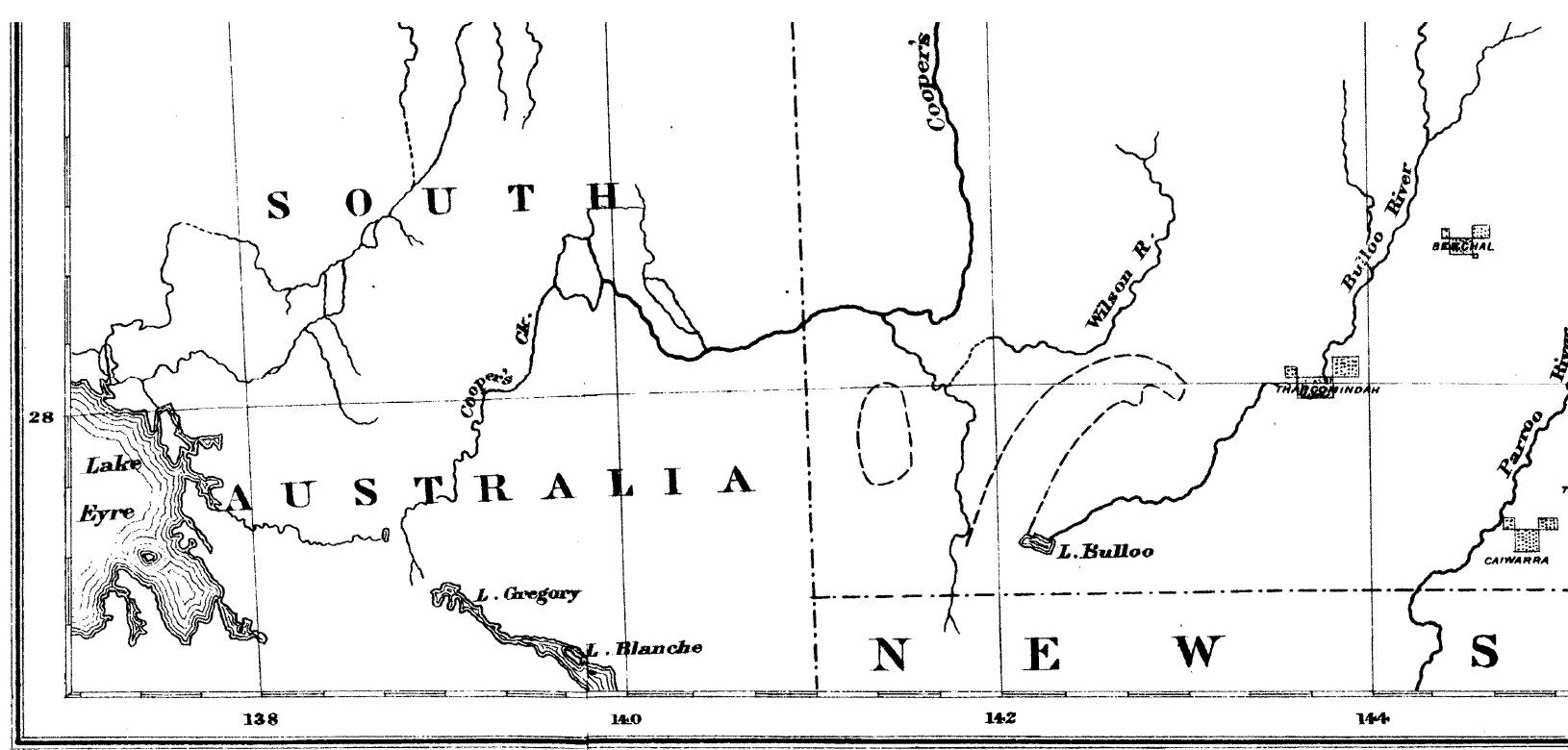

Published by the 


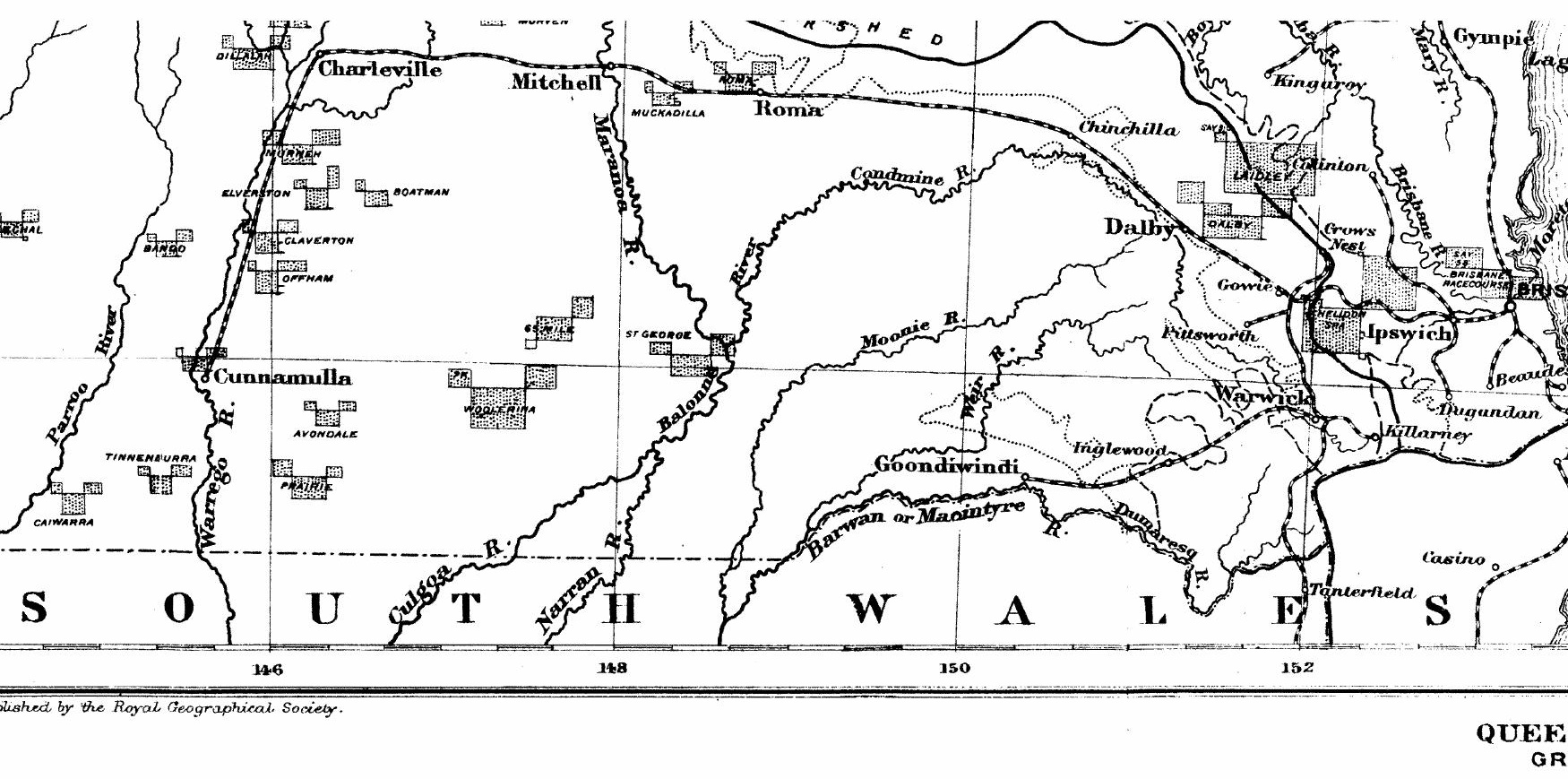




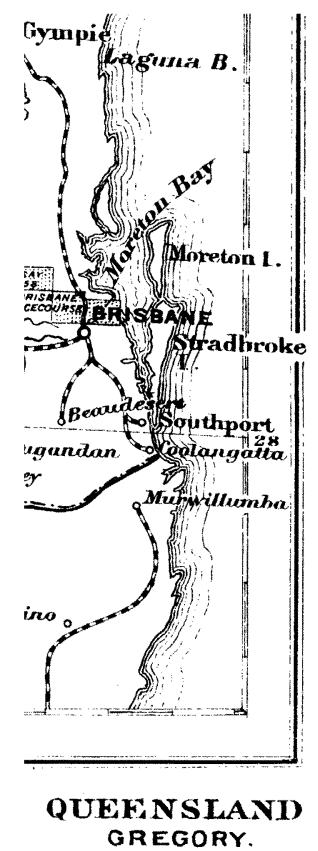

This content downloaded from 128.252.67.66 on Sun, 12 Jun 2016 06:11:55 UTC All use subject to http://about.jstor.org/terms 